\title{
EFFECT OF THE MINERAL NUTRITION OF POTATO PLANTS ON THE BIOCHEMISTRY AND THE PHYSIOLOGY OF THE TUBERS ${ }^{1}$ )
}

\author{
E. G. MULDER ${ }^{2}$ ) \\ Agricultural Experiment Station and Institute for Soil \\ Research T.N.O., Groningen
}

\begin{abstract}
SUMMARY
1 An investigation was made into the effect of the nitrogen, phosphorus and potassium nutrition of potato plants on the amino-acid composition of the tubers. The free aminoacids were determined as well as those contained in the protein. No correlation was found to exist between the amino-acid composition of the soluble non-protein fraction and that of the protein. Tyrosine, glutamic acid, arginine, $\gamma$-aminobutyric acid and the amides asparagine and glutamine occur in much greater amounts in the soluble non-protein fraction than in the protein fraction, whereas glycine, alanine, serine, threonine, the leucines, proline and lysine are found more abundantly in the protein. The amino-acid composition of the soluble non-protein fraction may be considerably affected by the mineral nutrition of the potato plants; that of the protein is independent of the mineral nutrition.

2 Stem-end blackening of potato tubers was found to be due to the enzymatical oxidation to melanin of tyrosine and other o-dihydric phenols. It occurs in the tubers of plants with an inadequate potassium supply. Such tubers are relatively rich in tyrosine. Moreover they are highly susceptible to injury. Owing to the operation of the latter factor tyrosine and $o$-dihydric phenols become subject to tyrosinase activity.

The bluish-green colour which may develop in potassium-deficient potatoes after boiling and exposure to the air was found to be due to the oxidation of the ferrous compound of o-dihydric phenols to the corresponding ferric compound. Iron reacts with $D$-dihydric phenols more readily in potassium-deficient potatoes than in normal tubers; this is probably owing to a lower citric acid content.

3 The effect was studied of the mineral nutrition of potato plants on the respiration of the tubers. Of the five nutrient elements tested (N, P, K, Mg and $\mathrm{Cu}$ ), potassium had by far the greatest effect on the rate of respiration. Potassium-deficient tubers were found to have considerably higher respiration rates than tubers grown on the same field with an optimum K-supply. This difference was found to be due to the fact that K-deficient and normal tubers differed as regards sensitiveness to bruising. The increased respiration rate of bruised tuber tissue is due to a stimulation of the respiration of the healthy cells by substances derived from the damaged cells.
\end{abstract}

\section{EFFECT OF THE MINERAL NUTRITION ON THE CHEMICAL COMPOSITION OF THE TUBERS}

Potato plants (Noordeling and Voran varieties) were grown on experimental fields laid out on soils poor in nitrogen, phosphorus, potassium, magnesium and copper respectively. In some cases the soils used were deficient in more than one nutrient element. The potato plants were dressed with varying amounts of the nutrient element in which the soil was deficient; the other nutrients were mostly supplied in optimum amounts.

The tubers were analyzed for protein, soluble non-protein nitrogen, and amino-acids. In the latter case the quantitative paper-chromatography method of Thompson and STEward (1952) was employed. The free amino-acids were determined as well as those contained in the protein (see MULdER and BAKEMA, 1956).

\footnotetext{
1) Paper read at the Informal Potato Conference held at Wageningen in August 1955.

2) Agronomist of the "Landbouwkundig Bureau der Nederlandse Stikstofmeststoffenindustrie".
} 
Tables 1, 2 and 3 show the results of analyses of $\mathrm{N}$-deficient, P-deficient and $\mathrm{K}$-deficient potato tubers. For the sake of comparison, the composition of normal tubers grown on the same experimental field with adequate amounts of $\mathrm{N}, \mathrm{P}$ and $\mathrm{K}$ is also recorded.

Table 1 Composition of the protein and the soluble non-protein fractions of potato tubers grown at two nitrogen levels, stored for 4 months

(Exp. 1388, 1952, var. Noordeling).

\begin{tabular}{|c|c|c|c|c|c|c|c|c|c|c|c|c|}
\hline \multirow{4}{*}{ Amino compound } & \multicolumn{6}{|c|}{ Low-N potatoes } & \multicolumn{6}{|c|}{ High-N potatoes } \\
\hline & \multicolumn{2}{|c|}{$\begin{array}{l}\text { Protein } \\
\text { fraction }\end{array}$} & \multicolumn{4}{|c|}{$\begin{array}{l}\text { Soluble non-protein } \\
\left.\text { fraction }{ }^{*}\right)\end{array}$} & \multicolumn{2}{|c|}{$\begin{array}{c}\text { Protein } \\
\text { fraction }\end{array}$} & \multicolumn{4}{|c|}{$\begin{array}{l}\text { Soluble non-protein } \\
\text { fraction }{ }^{*} \text { ) }\end{array}$} \\
\hline & \multirow{2}{*}{$\begin{array}{c}\mathrm{g} \\
\text { am.- } \\
\text { acid } \\
\text { per } \\
100 \mathrm{~g} \\
\text { pro- } \\
\text { tein } \\
(16 \\
\mathrm{g} \mathrm{N})\end{array}$} & \multirow{2}{*}{$\begin{array}{l}\mathrm{N} \text { as } \\
\% \text { of } \\
\text { sum } \\
\text { of } \\
\text { est. } \\
\text { am.- } \\
\text { acid- } \\
\mathrm{N} \\
\text { (incl. } \\
\mathrm{NH}_{3} \text { ) }\end{array}$} & \multicolumn{2}{|c|}{$\begin{array}{c}\mathrm{g} \text { am.-acid } \\
\text { per } 16 \mathrm{~g} \\
\text { am.- } \\
\text { acid-N }\end{array}$} & \multicolumn{2}{|c|}{$\begin{array}{l}\mathrm{N} \text { as } \% \text { of } \\
\text { sum of est. } \\
\text { am.- } \\
\text { acid-N }\end{array}$} & \multirow{2}{*}{\begin{tabular}{|c}
$\mathrm{g}$ \\
am.- \\
acid \\
per \\
$100 \mathrm{~g}$ \\
pro- \\
tein \\
$(16$ \\
$\mathrm{g} \mathrm{N})$
\end{tabular}} & \multirow{2}{*}{$\begin{array}{l}\mathrm{N} \text { as } \\
\% \text { of } \\
\text { sum } \\
\text { of } \\
\text { est. } \\
\text { am.- } \\
\text { acid- } \\
\mathrm{N} \\
\text { (incl. } \\
\mathrm{NH}_{3} \text { ) }\end{array}$} & \multicolumn{2}{|c|}{$\begin{array}{l}\text { g am.-acid } \\
\text { per } 16 \mathrm{~g} \\
\text { am.- } \\
\text { acid- } \mathrm{N}\end{array}$} & \multicolumn{2}{|c|}{$\begin{array}{l}\mathrm{N} \text { as } \% \text { of } \\
\text { sum of est. } \\
\text { am.- } \\
\text { acid-N }\end{array}$} \\
\hline & & & $\begin{array}{l}\text { incl. } \\
\text { the } \\
\text { am- } \\
\text { ides }\end{array}$ & $\begin{array}{l}\text { excl. } \\
\text { the } \\
\text { am- } \\
\text { ides }\end{array}$ & $\begin{array}{l}\text { incl. } \\
\text { the } \\
\text { am- } \\
\text { ides }\end{array}$ & $\begin{array}{l}\text { excl. } \\
\text { the } \\
\text { am- } \\
\text { ides }\end{array}$ & & & $\begin{array}{l}\text { incl. } \\
\text { the } \\
\text { am- } \\
\text { ides }\end{array}$ & $\begin{array}{l}\text { excl. } \\
\text { the } \\
\text { am- } \\
\text { ides }\end{array}$ & $\begin{array}{l}\text { incl. } \\
\text { the } \\
\text { am- } \\
\text { ides }\end{array}$ & $\begin{array}{l}\text { excl. } \\
\text { the } \\
\text { am- } \\
\text { ides }\end{array}$ \\
\hline Glycine & 5. & 7.5 & $\operatorname{tr}$ & $\operatorname{tr}$ & $\operatorname{tr}$ & $\operatorname{tr}$ & 6.0 & 7.6 & $\operatorname{tr}$ & $\operatorname{tr}$ & $\operatorname{tr}$ & $\operatorname{tr}$ \\
\hline Alar & 5 & 5.4 & 1.0 & 2.3 & 1.0 & 2.3 & 5. & 5.4 & 0.6 & 2.2 & 0.6 & 2.2 \\
\hline Seri & 6.8 & 6.2 & 1.0 & 2.3 & o. & 2 & 7. & 6.6 & 0.6 & 2 & 0.5 & 1 \\
\hline Cystine + cysteine & 1. & 0.7 & 0. & 1.6 & 0. & 0 & 1.8 & 0.8 & 0.3 & 1.1 & 0.2 & 0.6 \\
\hline Threonine ..... & 6. & 5.2 & 1. & 2.9 & 0. & 2. & 6.5 & 5.2 & 0.6 & 2 & 0.5 & 1 \\
\hline Valine $\ldots \ldots$ & 6.9 & 5.7 & 2.8 & 6.3 & 2.1 & 5.0 & 6.5 & 5.4 & 1.7 & 6.0 & 1.3 & 4.5 \\
\hline $\begin{array}{l}\text { Methionine + methi- } \\
\text { onine sulphoxide }\end{array}$ & 2 & 1.7 & 1.9 & 4 & & 2.6 & 3.1 & 2.0 & 1.0 & 3.3 & 0.6 & 2.0 \\
\hline Leucines . . . . . & 16.2 & 11.8 & 3.3 & 7.5 & 2.2 & 5.1 & 16.3 & 11.9 & 2.2 & 7.5 & 1.4 & 5.0 \\
\hline Phenylalanine ... & 5. & 2.9 & - & - & - & - & 4.9 & 2.8 & & & & \\
\hline Tyrosine $\ldots$ & 4. & 2.2 & 2.1 & 4.8 & 1.0 & 2. & 4.6 & 2.4 & 1.3 & 4.5 & 0.6 & 2.2 \\
\hline Prol & 3. & 3.2 & $\operatorname{tr}$ & $\operatorname{tr}$ & $\operatorname{tr}$ & $\operatorname{tr}$ & 3.8 & 3.2 & $\operatorname{tr}$ & $\operatorname{tr}$ & $\operatorname{tr}$ & $\operatorname{tr}$ \\
\hline Tryptophane & 1. & 1.6 & - & - & - & - & 2.0 & 1.9 & - & - & - & - \\
\hline Aspartic acid & 10 & 7.5 & 5.9 & 13.7 & 4.0 & 9.3 & 10.5 & 7.5 & 4.1 & 14.2 & 2.7 & 9.3 \\
\hline Glutamic acid . . & 9. & 6.4 & 20.6 & 47.4 & 12. & 29.3 & 9.8 & 6.3 & 10.3 & 35.3 & 6.1 & 21.1 \\
\hline Arginine $\ldots \ldots$ & 5. & 12.7 & 5.4 & 12.4 & 11.0 & 25.9 & 5.5 & 12.1 & 4.8 & 16.5 & 9.6 & 33.2 \\
\hline Lysir & 4. & 5.4 & $\operatorname{tr}$ & $\operatorname{tr}$ & $\operatorname{tr}$ & $\operatorname{tr}$ & 4.0 & 5.2 & $\operatorname{tr}$ & $\operatorname{tr}$ & $\operatorname{tr}$ & $\operatorname{tr}$ \\
\hline Histidine & 2. & 4.6 & 1.0 & 2.3 & 1. & 4. & 2.6 & 4.8 & 0.6 & 1.5 & 0.9 & 3.2 \\
\hline$\gamma$-Aminobutyric acid & 0.0 & 0.0 & 4.2 & 9.7 & 3.6 & 8.5 & 0.0 & 0.0 & 4.6 & 15.8 & 3.9 & 13.4 \\
\hline Asparagine . . . . & - & - & 34.6 & - & 46.4 & - & - & - & 41.4 & - & 54.9 & - \\
\hline Glutamine & - & - & 9.1 & - & 11.1 & - & - & - & 13.3 & - & 15.9 & - \\
\hline Ammonia & 1.7 & 9.3 & - & - & - & - & 1.6 & 9.0 & - & - & - & - \\
\hline
\end{tabular}

*) $91.9 \%$ and $76.2 \%$ of the Kjeldahl nitrogen of the protein and the soluble non-protein fractions of the low- $\mathrm{N}$ potatoes are accounted for by the amino-acid analyses of these fractions. For the high-N potatoes these values are $91.6 \%$ and $81.8 \%$, respectively.

On comparing the content of amino-acids occurring in the free state with that of amino-acids present in the protein, it will be seen that no correlation exists. In the soluble non-protein fraction the nitrogen of the amides constitutes more than $60 \%$ and occasionally more than $70 \%$ of the total amino-acid nitrogen. In the case of protein a maximum of $20 \%$ could be combined as amides, assuming that all the ammonia in the hydrolysate came from these compounds. When the amides are excluded, arginine accounts for approximately $30 \%$ of the amino-acid-N of the non-protein fraction; glutamic acid is the second or 
third most important amino-acid of this fraction, $\gamma$-aminobutyric acid the third, and in some cases the second.

Unlike the non-protein fraction, $\gamma$-aminobutyric acid does not occur in the protein. Arginine accounts for only approximately $10 \%$ of the protein-N,

Table 2 Composition of the protein and the soluble non-protein fractions of potato tubers grown at two phosphorus levels, stored for 1 month

(Exp. 1472, 1954, var. Noordeling).

\begin{tabular}{|c|c|c|c|c|c|c|c|c|c|c|c|c|}
\hline \multirow{4}{*}{ Amino compound } & \multicolumn{6}{|c|}{ Low-P potatoes } & \multicolumn{6}{|c|}{ High-P potatoes } \\
\hline & \multicolumn{2}{|c|}{$\begin{array}{l}\text { Protein } \\
\text { fraction }\end{array}$} & \multicolumn{4}{|c|}{$\begin{array}{l}\text { Soluble non-protein } \\
\text { fraction *) }\end{array}$} & \multicolumn{2}{|c|}{$\begin{array}{l}\text { P'rotein } \\
\text { fraction }{ }^{*} \text { ) }\end{array}$} & \multicolumn{4}{|c|}{$\begin{array}{l}\text { Soluble non-protein } \\
\text { fraction }{ }^{*} \text { ) }\end{array}$} \\
\hline & \multirow{2}{*}{$\begin{array}{c}\mathrm{g} \\
\text { am.- } \\
\text { acid } \\
\text { per } \\
100 \mathrm{~g} \\
\text { pro- } \\
\text { tein } \\
(16 \\
\mathrm{g} \mathrm{N})\end{array}$} & \multirow{2}{*}{$\begin{array}{l}\mathrm{N} \text { as } \\
\% \text { of } \\
\text { sum } \\
\text { of } \\
\text { est. } \\
\text { am.- } \\
\text { acid- } \\
\mathrm{N} \\
\text { (incl. } \\
\mathrm{NH}_{3} \text { ) }\end{array}$} & \multicolumn{2}{|c|}{$\begin{array}{c}\mathrm{g} \text { am.-acid } \\
\text { per } 16 \mathrm{~g} \\
\text { am.- } \\
\text { acid-N }\end{array}$} & \multicolumn{2}{|c|}{$\begin{array}{l}\mathrm{N} \text { as } \% \text { of } \\
\text { sum of est. } \\
\text { am.- } \\
\text { acid- } \mathrm{N}\end{array}$} & \multirow{2}{*}{$\begin{array}{c}\mathrm{g} \\
\text { am.- } \\
\text { acid } \\
\text { per } \\
100 \mathrm{~g} \\
\text { pro- } \\
\text { tein } \\
(16 \\
\mathrm{g} \mathrm{N})\end{array}$} & \multirow{2}{*}{$\begin{array}{l}\mathrm{N} \text { as } \\
\% \text { of } \\
\text { sum } \\
\text { of } \\
\text { est. } \\
\text { am.- } \\
\text { acid- } \\
\mathrm{N} \\
\text { (incl. } \\
\mathrm{NH}_{3} \text { ) }\end{array}$} & \multicolumn{2}{|c|}{$\begin{array}{c}\mathrm{g} \mathrm{am} \text {-acid } \\
\text { per } 16 \mathrm{~g} \\
\text { am.- } \\
\text { acid-N }\end{array}$} & \multicolumn{2}{|c|}{$\begin{array}{c}\mathrm{N} \text { as } \% \text { of } \\
\text { sum of est } \\
\text { am.- } \\
\text { acid- } \mathrm{N}\end{array}$} \\
\hline & & & $\begin{array}{l}\text { incl. } \\
\text { the } \\
\text { am- } \\
\text { ides }\end{array}$ & $\begin{array}{l}\text { excl. } \\
\text { the } \\
\text { am- } \\
\text { ides }\end{array}$ & $\begin{array}{l}\text { incl. } \\
\text { the } \\
\text { am- } \\
\text { ides }\end{array}$ & $\begin{array}{l}\text { excl. } \\
\text { the } \\
\text { am- } \\
\text { ides }\end{array}$ & & & $\begin{array}{l}\text { incl. } \\
\text { the } \\
\text { am- } \\
\text { ides }\end{array}$ & $\begin{array}{l}\text { excl. } \\
\text { the } \\
\text { am- } \\
\text { ides }\end{array}$ & $\begin{array}{l}\text { incl. } \\
\text { the } \\
\text { am- } \\
\text { ides }\end{array}$ & $\begin{array}{l}\text { excl. } \\
\text { the } \\
\text { am- } \\
\text { ides }\end{array}$ \\
\hline Glycine . . & 5 & 7 & 0 & 1 & 0.6 & 2.3 & 5 . & 8.0 & 1.0 & 2.8 & 1.1 & 3.4 \\
\hline Alanine & & 4. & 0. & 2 & 0 & 2. & 4 & 5.0 & 0 & & 0 & 2.1 \\
\hline Serine . & 5.8 & 5.8 & 0.8 & 3. & 0.7 & 2.8 & 6.0 & 5.9 & 1. & 3 & 1.1 & 3 \\
\hline Cystine + cysteine. & 0.6 & 0.4 & 0.2 & 0. & 0.1 & 0. & 0.7 & 0.5 & 0. & 0 & 0.1 & 0.4 \\
\hline Threonine .... & 6.6 & 5.3 & 0.8 & 3.3 & 0.6 & 2. & 5.8 & 5.1 & 1.0 & 3. & 0.8 & 2.3 \\
\hline Valine $\ldots$. & 7.3 & 6.7 & 2.2 & 8.8 & 1.7 & 6.6 & 7.6 & 6.7 & 2.8 & 8.3 & 2.1 & 6.2 \\
\hline $\begin{array}{l}\text { Methionine + methi- } \\
\text { onine sulphoxide. }\end{array}$ & 1.9 & 1.3 & 1.2 & & 0.7 & 2.8 & 2.0 & 1.4 & 2.0 & 5 & 1.2 & 3.5 \\
\hline Leucines & 17.0 & 13.8 & 1.7 & 6.7 & 1.3 & 4.5 & 17.9 & 14.1 & 2.1 & 6.2 & 1.4 & 4.1 \\
\hline Phenylalanine & 5.0 & 3.3 & 1.9 & 7.6 & 1.0 & 4.0 & 5.3 & 3.3 & 1. & 5.3 & 1.0 & 2.8 \\
\hline Tyrosine ... & 4.5 & 2.7 & 1.2 & 4.6 & 0.6 & 2. & 4. & 2.6 & 2.7 & 7.8 & 1.3 & 3.7 \\
\hline Prolir & 3.6 & 3.3 & $\operatorname{tr}$ & $\operatorname{tr}$ & $\operatorname{tr}$ & tr & 3. & 3.2 & tr & $\operatorname{tr}$ & $\operatorname{tr}$ & $\operatorname{tr}$ \\
\hline Tryptophane & 1.8 & 1.8 & - & - & - & - & 1. & 1.9 & - & - & - & _ \\
\hline acid & 8. & 6. & 2.2 & 8.6 & 1.4 & 5.6 & 8 & 6.3 & 2.7 & 7.8 & 1.8 & 5.1 \\
\hline Glutamic acid & 9. & 6.9 & 7.6 & 30. & 4.5 & 18.0 & 10.0 & 7.0 & 10.9 & 31.8 & 6.5 & 19.0 \\
\hline Arginine $\ldots$ & 3. & 7.8 & 3.4 & 13.4 & 6.8 & 27.0 & 3. & 8.0 & 2.9 & 8.6 & 5.9 & 17.1 \\
\hline Lysine & 3.7 & 5. & tr & tr & tr & tr & 3. & 5.5 & tr & $\operatorname{tr}$ & $\operatorname{tr}$ & tr \\
\hline Histidine & 3.1 & 6.4 & 0.8 & 3.2 & 1.4 & 5.4 & 3. & 6.0 & 1.3 & 3.8 & 2.2 & 6.4 \\
\hline$\gamma$-Aminobutyric acid & 0.0 & 0.0 & 4.1 & 16.4 & 3.5 & 14.0 & 0.0 & 0.0 & 8.6 & 25.0 & 7.3 & 21.2 \\
\hline Asparagine . . & - & - & 37.3 & - & $\mathbf{5 2 . 4}$ & - & - & - & 32.3 & - & 43.1 & - \\
\hline Glutamine & - & - & 18.6 & - & 22.3 & - & - & - & 18.7 & - & 22.4 & - \\
\hline Ammonia & 1.7 & 10.3 & 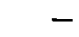 & - & - & - & 1.6 & 9.5 & 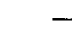 & - & - & - \\
\hline
\end{tabular}

*) $82.5 \%$ and $70.0 \%$ of the Kjeldahl nitrogen of the protein and the soluble non-protein fractions of the low-P potatoes are accounted for by the amino-acid analyses of these fractions. For the high-P potatoes these values are $84.8 \%$ and $71.5 \%$, respectively.

glutamic acid for about $6 \%$. A number of amino-acids occur much more abundantly in the protein than in the free state. These are glycine, alanine, serine, threonine, the leucines, proline and lysine.

Although the mineral nutrition $(\mathrm{N}, \mathrm{P}$ and $\mathrm{K}$ ) of the potato plants examined in this investigation had a pronounced effect on the yield and protein content of the tubers (see Table 4) it did not affect the amino-acid composition of the protein (Tables 1, 2 and 3).

There was, however, considerable variation in the composition of the soluble 
non-protein fraction. In the soluble non-protein fraction of $n$ itrogendeficient potatoes $57.5 \%$ of the estimated nitrogen was accounted for by amides. In the tubers of fully manured plants this value was more than $70 \%$. When the amides were excluded, glutamic acid was found to be considerably more abundant in $\mathrm{N}$-deficient tubers than in potatoes with a liberal nitrogen supply. Arginine and $\gamma$-aminobutyric acid occurred more abundantly in the latter tubers. Apparently both arginine and $\gamma$-aminobutyric acid act as storage compounds for excessive nitrogen, in the same way as the amides.

P-d eficient potatoes were found to be higher in soluble non-protein nitrogen than tubers from plants dressed liberally with phosphorus. Approximately $75 \%$ of the soluble non-protein nitrogen occurred as amides in the P-deficient potatoes; in the normal tubers this value was $65 \%$. This difference was wholly accounted for by asparagine. Arginine occurred more abundantly in P-deficient tubers than in normal ones, $\gamma$-aminobutyric acid less abundantly.

Table 3 Composition of the protein and the soluble non-protein fractions of potato tubers grown at two potassium levels, stored for 3 months

(Exp. 1299, 1952, var. Noordeling).

\begin{tabular}{|c|c|c|c|c|c|c|c|c|c|c|c|c|}
\hline \multirow{4}{*}{ Amino compound } & \multicolumn{6}{|c|}{ Low-K potatoes } & \multicolumn{6}{|c|}{ High-K potatoes } \\
\hline & \multicolumn{2}{|c|}{$\begin{array}{l}\text { Protein } \\
\text { fraction }\end{array}$} & \multicolumn{4}{|c|}{$\begin{array}{l}\text { Soluble non-protein } \\
\left.\text { fraction }{ }^{\circ}\right)\end{array}$} & \multicolumn{2}{|c|}{$\begin{array}{l}\text { Protein } \\
\text { fraction }\end{array}$} & \multicolumn{4}{|c|}{$\begin{array}{l}\text { Soluble non-protein } \\
\text { fraction }{ }^{\circ} \text { ) }\end{array}$} \\
\hline & \multirow{2}{*}{$\begin{array}{c}\mathrm{g} \\
\text { am.- } \\
\text { acid } \\
\text { per } \\
100 \mathrm{~g} \\
\text { pro- } \\
\text { tein } \\
(16 \\
\mathrm{g} \mathrm{N})\end{array}$} & \multirow{2}{*}{$\begin{array}{c}\mathrm{N} \text { as } \\
\% \text { of } \\
\text { sum } \\
\text { of } \\
\text { est. } \\
\text { am.- } \\
\text { acid- } \\
\mathrm{N} \\
\left(\mathrm{incl}^{2}\right. \\
\mathrm{NH}_{3} \text { ) }\end{array}$} & \multicolumn{2}{|c|}{$\begin{array}{c}\mathrm{g} \mathrm{am} .-\mathrm{acid} \\
\text { per } 16 \mathrm{~g} \\
\text { am.- } \\
\text { acid-N }\end{array}$} & \multicolumn{2}{|c|}{$\begin{array}{l}\mathrm{N} \text { as } \% \text { of } \\
\text { sum of est. } \\
\text { am.- } \\
\text { acid- } \mathrm{N}\end{array}$} & \multirow{2}{*}{$\begin{array}{c}\mathrm{g} \\
\text { am.- } \\
\text { acid } \\
\text { per } \\
100 \mathrm{~g} \\
\text { pro- } \\
\text { tein } \\
(16 \\
\mathrm{g} \mathrm{N})\end{array}$} & \multirow{2}{*}{$\begin{array}{l}\mathrm{N} \text { as } \\
\% \text { of } \\
\text { sum } \\
\text { of } \\
\text { est. } \\
\text { am.- } \\
\text { acid- } \\
\mathrm{N} \\
(\text { incl. } \\
\left.\mathrm{NH}_{3}\right)\end{array}$} & \multicolumn{2}{|c|}{$\begin{array}{c}\mathrm{g} \text { am.-acid } \\
\text { per } 16 \mathrm{~g} \\
\text { am.- } \\
\text { acid-N }\end{array}$} & \multicolumn{2}{|c|}{$\begin{array}{c}\mathrm{N} \text { as } \% \text { of } \\
\text { sum of est. } \\
\text { am.- } \\
\text { acid-N }\end{array}$} \\
\hline & & & $\begin{array}{l}\text { incl. } \\
\text { the } \\
\text { am- } \\
\text { ides }\end{array}$ & $\begin{array}{l}\text { excl. } \\
\text { the } \\
\text { am- } \\
\text { ides }\end{array}$ & $\begin{array}{l}\text { incl. } \\
\text { the } \\
\text { am- } \\
\text { ides }\end{array}$ & $\begin{array}{l}\text { excl. } \\
\text { the } \\
\text { am- } \\
\text { ides }\end{array}$ & & & $\begin{array}{l}\text { incl. } \\
\text { the } \\
\text { am- } \\
\text { ides }\end{array}$ & $\begin{array}{l}\text { excl. } \\
\text { the } \\
\text { am- } \\
\text { ides }\end{array}$ & $\begin{array}{l}\text { incl. } \\
\text { the } \\
\text { am- } \\
\text { ides }\end{array}$ & $\begin{array}{l}\text { excl. } \\
\text { the } \\
\text { am- } \\
\text { ides }\end{array}$ \\
\hline Glycine & 5.3 & 7.0 & $\operatorname{tr}$ & $\operatorname{tr}$ & $\operatorname{tr}$ & $\operatorname{tr}$ & 5.4 & 6.9 & $\operatorname{tr}$ & $\operatorname{tr}$ & $\operatorname{tr}$ & $\operatorname{tr}$ \\
\hline Alani & 5.9 & 6.6 & 0.6 & 1.7 & 0.5 & 1.7 & 6 & 6 & 0.6 & 1. & 0.6 & 1.7 \\
\hline Serin & 6.6 & 6.2 & 1.3 & 4.1 & 1.1 & 3.4 & 6. & 5.6 & 1.5 & 4 & 1.3 & 3.8 \\
\hline Cystine + cysteine & 1.0 & 0.6 & 0.4 & 1.3 & 0. & 1. & 0 . & 0.4 & 0.5 & & & 0.8 \\
\hline Threonine & 6.7 & 5.6 & 1.2 & 3.7 & 0.8 & 2.7 & 6.5 & 5.3 & 1.3 & 3 & 1.0 & 2.8 \\
\hline Valine $\ldots \ldots$ & 5.9 & 5.0 & 3.0 & 9.2 & 2.3 & 6.9 & 6.2 & 5.1 & 2.6 & 7.6 & 1.9 & 5.7 \\
\hline Methionine + methi- & & & & & & & & & & & & \\
\hline & 2.5 & 1.7 & 1.5 & 4.5 & 0.9 & 2.7 & 2.3 & 1.4 & 1.7 & 4.9 & 1.0 & 2.9 \\
\hline Leucines & 15.3 & 11.6 & 1.9 & 5. & 1.3 & 3.9 & 15.2 & 11.3 & 1.7 & 5 & 1.1 & 3.4 \\
\hline Phenylalanine & 5.5 & 33 & 2.3 & 6. & 1. & 3. & 5. & 3.2 & 1.4 & 4 & 0.8 & 2.2 \\
\hline Tyrosine $\ldots$ & 5.2 & 2.8 & 5.2 & 15.9 & 2.5 & 7.7 & 5. & 2.7 & 3.3 & 9.7 & 1.6 & 4.7 \\
\hline Proline & 4.3 & 3.7 & $\operatorname{tr}$ & $\operatorname{tr}$ & $\operatorname{tr}$ & $\operatorname{tr}$ & 5. & 4.4 & $\operatorname{tr}$ & $\operatorname{tr}$ & tr & $\operatorname{tr}$ \\
\hline Tryptophane & 1.9 & 1.8 & - & 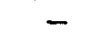 & - & - & 1.8 & 1.7 & - & - & - & \\
\hline Aspartic acid & 10.3 & 7.7 & 2.8 & 8.4 & 1.8 & 5.6 & 10.5 & 7.7 & 3.9 & 11.4 & 2.5 & 7.5 \\
\hline Glutamic acid & 9.4 & 6.4 & 5.8 & 17.8 & 3.5 & 10.6 & 9.9 & 6.6 & 8.6 & 25.3 & 5.1 & 15.1 \\
\hline Arginine $\ldots$ & 4. & 9. & 4.6 & 14.0 & 9.2 & 28.0 & 4. & 9.8 & 5.2 & 15.3 & 10.4 & 30.7 \\
\hline Lysi & 4.6 & 6.2 & 0.7 & 2.2 & 0.9 & 2.7 & 5. & 6. & 0.8 & 2 & 1.0 & 2.9 \\
\hline Histid & 2.6 & 5.0 & 0.6 & 1.8 & 1.0 & 3.1 & 2.4 & 4. & 0.6 & $\bar{l}$ & & 3.1 \\
\hline$\gamma$-Aminobutyric acid & 0.0 & 0.0 & 6.4 & 19.5 & 5.4 & 16.6 & 0.0 & 0.0 & 5.2 & 15.5 & 4.5 & 13.1 \\
\hline As & - & - & 37.9 & - & 50.3 & - & - & - & 38.6 & - & 51.2 & - \\
\hline Glutamine & - & - & 14.1 & - & 16.8 & - & - & - & 12.3 & - & 14.8 & - \\
\hline Ammonia . & 1.6 & 9.3 & - & - & - & - & 1.8 & 10.0 & - & - & - & - \\
\hline
\end{tabular}

*) $88.2 \%$ and $87.8 \%$ of the Kjeldahl nitrogen of the protein and the soluble non-protein fractions of the low-K potatoes are accounted for by the amino-acid analyses of these fractions. For the high-K potatoes these values are $89.9 \%$ and $89.1 \%$, respectively. 
Table 4 Yield data and protein and soluble non-protein N-contents of the potato tubers used for the aminc-acid analyses.

\begin{tabular}{c|c|c|c|c}
\hline \multirow{2}{*}{ Exp., year, variety } & $\begin{array}{c}\text { Manurial } \\
\text { treatment } \\
\text { (kg per ha) }\end{array}$ & $\begin{array}{c}\text { Yield, q per ha } \\
(1 \mathrm{q}=100 \mathrm{~kg})\end{array}$ & $\begin{array}{c}\text { mg N per } 10 \mathrm{~g} \text { dry weight } \\
\begin{array}{c}\text { Protein } \\
\text { fraction }\end{array}\end{array}$ & $\begin{array}{c}\text { Soluble non- } \\
\text { protein fraction }\end{array}$ \\
\hline 1388, 1952, Noordeling & $40 \mathrm{~N}$ & 103 & 78.7 & 32.8 \\
& $160 \mathrm{~N}$ & 183 & 107.4 & 66.6 \\
1472,1954 , Noordeling & $0 \mathrm{P}_{5} \mathrm{O}_{5}$ & 44 & 85.5 & 84.4 \\
1299,1952, Noordeling & $300 \mathrm{P}_{5} \mathrm{O}_{5}$ & 290 & 62.5 & 44.8 \\
& $0 \mathrm{~K}_{2} \mathrm{O}$ & 108 & 106.4 & 106.9 \\
& $200 \mathrm{~K}_{2} \mathrm{O}$ & 290 & 93.4 & 86.4 \\
\hline
\end{tabular}

-) $\mathrm{N}$ was supplied as ammonium nitrate limestone, $\mathrm{P}$ as superphosphate; and $\mathrm{K}$ as potassium sulphate.

In $\mathrm{K}$-d ef icie nt potatoes phenylalanine and tyrosine accounted for considerably more of the amino-acid- $\mathrm{N}$ than in tubers dressed adequately with potassium. Glutamic acid was found in smaller amounts in K-deficient than in $\mathrm{K}$-supplied tubers.

Table 5 Effect of the nitrogen nutrition of potato plants on the amino-acid content of the tubers (calculated as $\mathrm{mg}$ amino-acid per $10 \mathrm{~g}$ of dry matter, cf. Table 1).

\begin{tabular}{|c|c|c|c|c|}
\hline \multirow[b]{2}{*}{ Amino compound } & \multicolumn{2}{|c|}{ Low-N potatoes } & \multicolumn{2}{|c|}{ High-N potatoes } \\
\hline & $\begin{array}{l}\text { Protein } \\
\text { fraction }\end{array}$ & $\begin{array}{l}\text { Soluble non- } \\
\text { protein fraction }\end{array}$ & $\begin{array}{l}\text { Protein } \\
\text { fraction }\end{array}$ & $\begin{array}{l}\text { Soluble non- } \\
\text { protein fraction }\end{array}$ \\
\hline 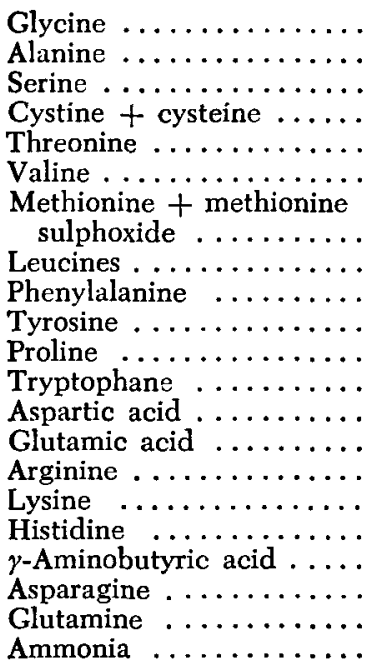 & $\begin{array}{r}29.0 \\
25.1 \\
3.3 .5 \\
5.4 \\
32.0 \\
33.9 \\
\\
13.8 \\
79.7 \\
24.6 \\
20.7 \\
18.7 \\
8.9 \\
51.7 \\
48.7 \\
28.5 \\
20.7 \\
12.3 \\
0.0 \\
- \\
8.4\end{array}$ & $\begin{array}{r}\operatorname{tr} \\
1.6 \\
1.6 \\
1.1 \\
2.0 \\
4.4 \\
\\
3.0 \\
5.2 \\
\overline{5} \\
\operatorname{tr} \\
\overline{\ln } \\
9.5 \\
32.9 \\
8.6 \\
\mathrm{tr} \\
1.6 \\
6.7 \\
55.3 \\
14.6 \\
-\end{array}$ & $\begin{array}{r}40.3 \\
33.6 \\
48.3 \\
8.7 \\
43.6 \\
43.6 \\
\\
20.8 \\
109.4 \\
32.9 \\
30.9 \\
25.5 \\
13.4 \\
70.5 \\
65.8 \\
36.9 \\
26.9 \\
17.5 \\
0.0 \\
-\overline{1} \\
10.7\end{array}$ & $\begin{array}{c}\text { tr } \\
2.2 \\
2.1 \\
1.1 \\
2.2 \\
5.9 \\
\\
3.3 \\
7.4 \\
\overline{4.4} \\
\text { tr } \\
14.0 \\
35.1 \\
16.3 \\
\text { tr } \\
1.9 \\
15.6 \\
141.3 \\
45.4 \\
-\end{array}$ \\
\hline
\end{tabular}

From the point of view of human and animal nutrition the amounts of amino acids per unit of dry matter contained in the protein, and occurring in the free state, are important data.

In Tables 5-7 these values have therefore been calculated per $10 \mathrm{~g}$ of dry matter. It will be seen that for a number of amino-acids the amount occurring in the protein is more than 10 times as high as that occurring in the free state. 
Table 6 Effect of the phosphorus nutrition of potato plants on the amino-acid content of the tubers (calculated as $\mathrm{mg}$ amino-acid per $10 \mathrm{~g}$ of dry matter, $c f$. Table 2).

\begin{tabular}{|c|c|c|c|c|}
\hline \multirow[b]{2}{*}{ Amino compound } & \multicolumn{2}{|c|}{ Low-P potatoes } & \multicolumn{2}{|c|}{ High-P potatoes } \\
\hline & $\begin{array}{c}\text { Protein } \\
\text { fraction }\end{array}$ & $\begin{array}{l}\text { Soluble non- } \\
\text { protein fraction }\end{array}$ & $\begin{array}{c}\text { Protein } \\
\text { fraction }\end{array}$ & $\begin{array}{l}\text { Soluble non- } \\
\text { protein fraction }\end{array}$ \\
\hline 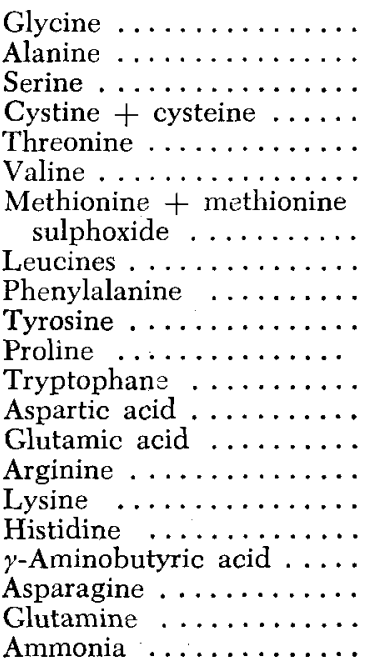 & $\begin{array}{r}28.9 \\
21.9 \\
31.0 \\
3.2 \\
32.1 \\
39.0 \\
\\
10.2 \\
90.8 \\
26.7 \\
24.0 \\
19.2 \\
9.6 \\
42.8 \\
50.8 \\
17.1 \\
19.7 \\
16.6 \\
0.0 \\
- \\
9.1\end{array}$ & $\begin{array}{r}1.8 \\
2.3 \\
2.9 \\
0.7 \\
3.1 \\
8.2 \\
\\
4.5 \\
6.3 \\
7.1 \\
4.3 \\
\operatorname{tr} \\
- \\
8.0 \\
28.2 \\
12.5 \\
\operatorname{tr} \\
3.0 \\
15.3 \\
137.8 \\
68.7 \\
-\end{array}$ & $\begin{array}{r}22.6 \\
16.8 \\
23.4 \\
2.7 \\
22.6 \\
29.7 \\
\\
7.8 \\
69.9 \\
20.7 \\
18.0 \\
14.1 \\
7.4 \\
31.6 \\
39.1 \\
13.3 \\
15.2 \\
11.7 \\
0.0 \\
- \\
6.3\end{array}$ & $\begin{array}{r}1.9 \\
1.4 \\
2.6 \\
0.5 \\
2.0 \\
5.5 \\
\\
3.8 \\
4.1 \\
3.5 \\
5.2 \\
\operatorname{tr} \\
-\overline{5} \\
5.2 \\
21.3 \\
5.7 \\
\operatorname{tr} \\
2.5 \\
16.7 \\
629 \\
36.3 \\
-\end{array}$ \\
\hline
\end{tabular}

Table 7 Effect of the potassium nutrition of potato plants on the amino-acid content of the tubers (calculated as $\mathrm{mg}$ amino-acid per $10 \mathrm{~g}$ of dry matter, cf. Table 3).

\begin{tabular}{|c|c|c|c|c|}
\hline \multirow[b]{2}{*}{ Amino compound } & \multicolumn{2}{|c|}{ Low-K potatoes } & \multicolumn{2}{|c|}{ High-K potatoes } \\
\hline & $\begin{array}{l}\text { Protein } \\
\text { fraction }\end{array}$ & $\begin{array}{l}\text { Soluble non- } \\
\text { protein fraction }\end{array}$ & $\begin{array}{l}\text { Protein } \\
\text { fraction }\end{array}$ & $\begin{array}{l}\text { Soluble non- } \\
\text { protein fraction }\end{array}$ \\
\hline 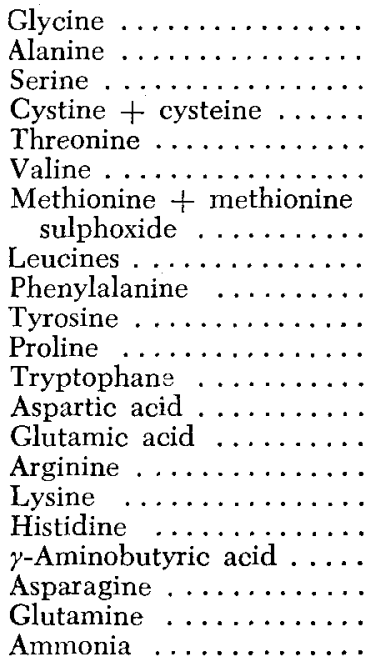 & $\begin{array}{r}35.2 \\
39.2 \\
43.9 \\
6.7 \\
44.5 \\
39.2 \\
\\
16.6 \\
101.8 \\
36.6 \\
34.6 \\
28.6 \\
12.6 \\
68.5 \\
62.5 \\
27.9 \\
30.6 \\
17.3 \\
0.0 \\
- \\
10.6\end{array}$ & $\begin{array}{r}\text { tr } \\
3.3 \\
7.9 \\
2.6 \\
7.2 \\
17.9 \\
\\
8.9 \\
11.5 \\
13.5 \\
30.9 \\
\operatorname{tr} \\
-\overline{1} \\
16.4 \\
34.7 \\
27.2 \\
4.3 \\
3.5 \\
38.0 \\
224.8 \\
83.5 \\
-\end{array}$ & $\begin{array}{r}31.5 \\
35.0 \\
35.0 \\
4.1 \\
38.0 \\
36.2 \\
13.4 \\
88.8 \\
31.5 \\
29.2 \\
30.4 \\
10.5 \\
61.3 \\
57.8 \\
25.6 \\
29.2 \\
14.0 \\
0.0 \\
- \\
10.5\end{array}$ & $\begin{array}{r}\text { tr } \\
2.7 \\
6.9 \\
2.4 \\
5.8 \\
11.5 \\
\\
7.4 \\
7.7 \\
6.4 \\
14.6 \\
\text { tr } \\
17.2 \\
38.2 \\
23.1 \\
3.7 \\
2.8 \\
23.4 \\
172.0 \\
55.0 \\
-\end{array}$ \\
\hline
\end{tabular}


In the case of serine, cystine, threonine, valine, methionine, tyrosine, aspartic acid, glutamic acid and arginine, however, the free amino-acids contribute considerably more to the total amount of amino-acids per unit of dry matter. In the case of tyrosine, glutamic acid and arginine the free amino-acids may constitute 30-50 per cent of the total.

By comparing samples of varying manurial treatment it will be seen that large differences occur. Tubers from plants amply supplied with nitrogen contained from 30 to 40 per cent higher amounts of practically every aminoacid. The content of $\gamma$-aminobutyric acid, asparagine and glutamine was more than doubled. In the case of phosphorus and potassium, the tubers from deficient plants had considerably higher contents of most amino-acids. It should be emphasized that this effect of mineral nutrition on amino-acid content works mainly through the protein content of the tubers (see Table 4) and only to a minor extent through the soluble non-protein fraction. The latter is of importance in the case of tyrosine, arginine, $\gamma$-aminobutyric acid, asparagine and glutamine.

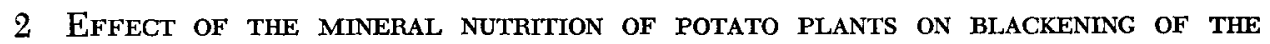
TUBERS ${ }^{3}$ )

There are two types of blackening in potato tubers related to the mineral nutrition viz. a) the bluish-black discolorations occurring in the stem half of tubers after rough handling, and b) the bluish-green discolorations found on boiling tuubers which were completely white beforehand.

This discoloration of living potatoes (enzymatical blackening) may vary from small bluish-black lesions, occurring between vascular ring and skin, to the discoloration of large areas of tissue at the stem end of the tubers. The latter is to be found in potatoes subjected to rough handling.

If the tubers were blackened before boiling they retain their black colour afterwards. Stem ends of tubers with a high liability to enzymatical blackening which are uncoloured before boiling may take on a grey, bluish-green colour afterwards.

\section{Effect of potassium}

Both types of discoloration are closely related to the potassium nutrition of the potato plants. This was shown in experiments with tubers grown on experimental fields at different potassium levels of the soil. The tubers were shaken in a flask for approximately 5 minutes, cut longitudinally and exposed to the air for a few hours. Where there was K-deficiency, large areas of the stem halves of the tubers turned red and thereafter black in a few hours. Tubers from plants moderately deficient in potassium showed a moderate blackening, whereas tubers from normal plants showed no discoloration at all (see Fig. 1).

For the complete prevention of blackening the amounts of potassium required are relatively high. A dressing which may be sufficient for obtaining optimum yields may be too low to prevent blackening. It must be borne in mind that secondary factors such as variety, handling during harvest and transportation, and conditions during storage (temperature, aeration) may considerably modify sensitivity to blackening. The age of the tubers is also important. Tubers

3) For a more detailed account of these investigations see MULDER (1949). 

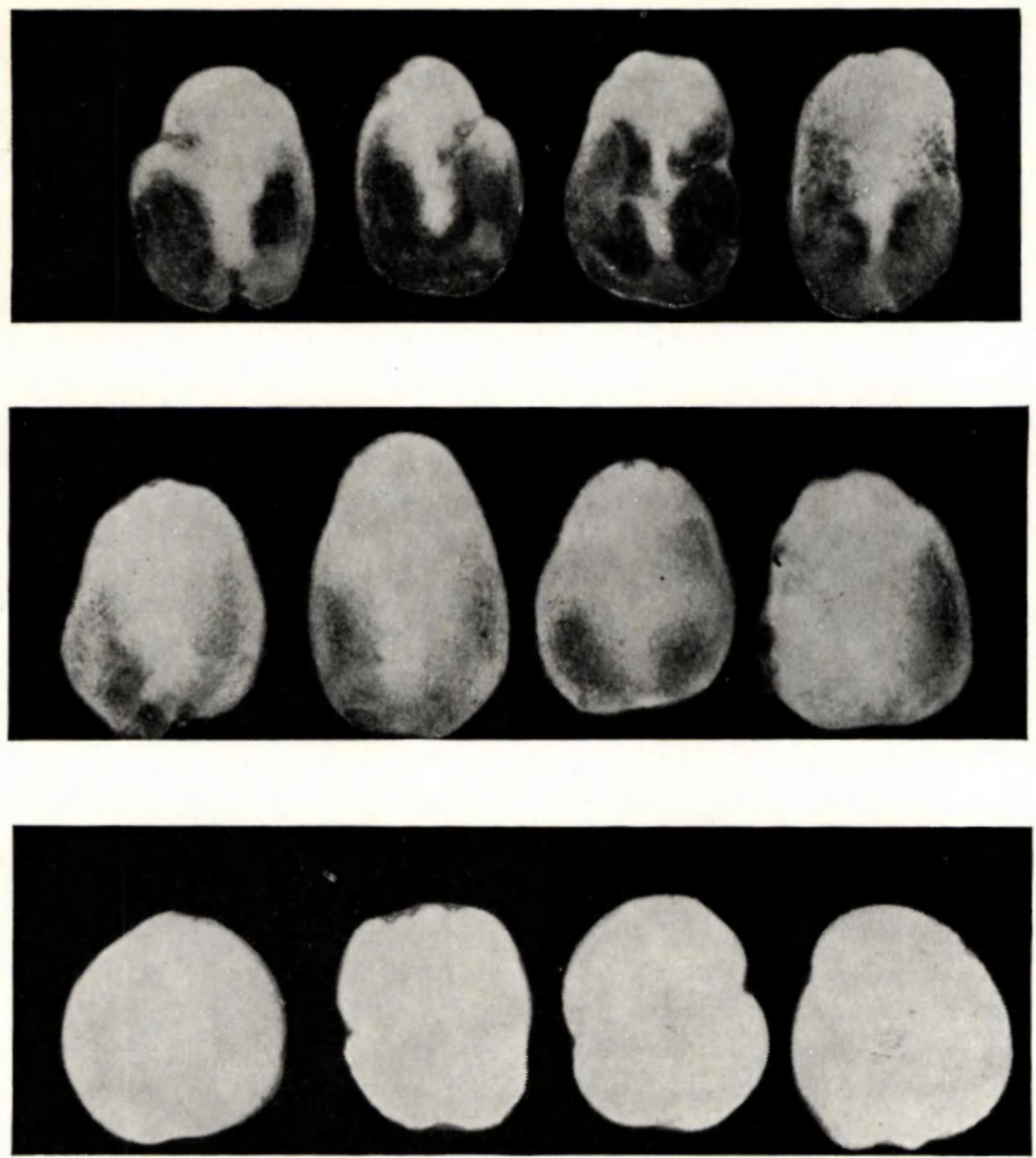

C

Fig. 1 Tubers from potato Plants With SEvere symptoms of K-DEFiciency (A), with SLIGHT SYMPTOMS (B), AND FROM NORMAL PLANTS (C).

with a moderate K-supply which are not liable to blackening before the winter may show a relatively high sensitivity to it afterwards.

Nitrogen, phosphorus, magnesium

Of the other nutrient elements tested phosphorus and magnesium were found to have no effect on the susceptibility of potatoes to enzymatical blackening. Nitrogen has a slight effect owing to the fact that large amounts of nitrogenous fertilizers may increase the plants' potassium requirements.

\section{Copper}

The copper supply of the potato plants was found to be a basic factor in the formation of black lesions in raw potatoes, owing to the fact that the enzyme tyrosinase, responsible for the formation of the black colour, contains copper as the prosthetic element (see Fig. 2). As a result tubers from plants deficient in both potassium and copper are largely free from blackening (Fig. 3). The copper requirement of potato plants is very low, however, so that potatoes 


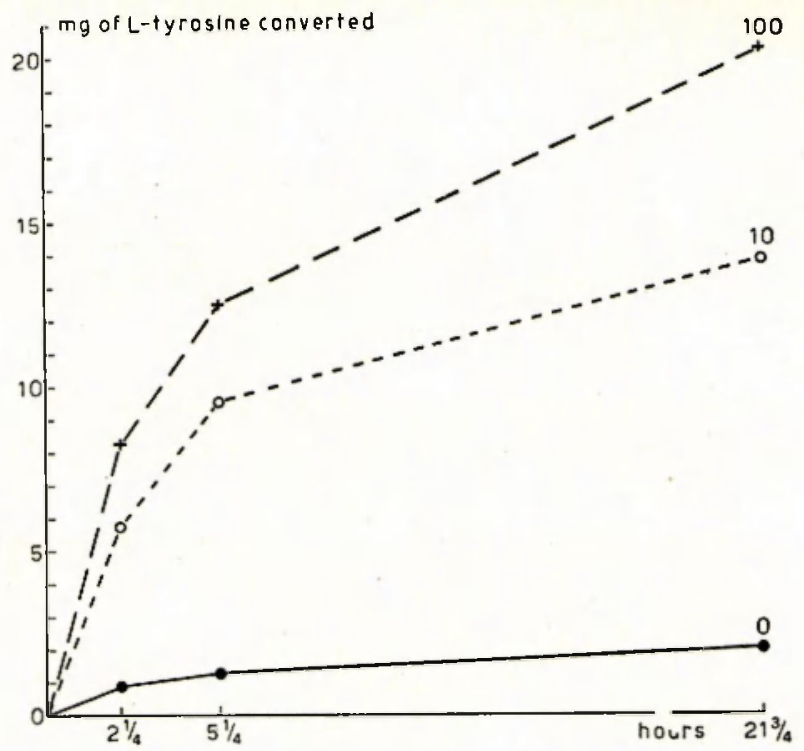

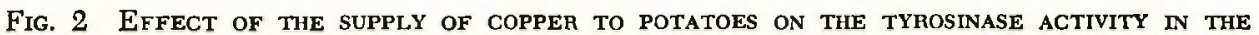
TUBERS, E.XP. 1011, JANUARY 19:9. $0=$ no copper, $10=$ copper sulphate at the rate of $10 \mathrm{~kg}$ per ha and $100=$ copper sulphate at the rate of $100 \mathrm{~kg}$ per ha. In all cases potassium was supplied at the rate of $400 \mathrm{~kg} \mathrm{~K} \mathrm{~K}_{2} \mathrm{O}$ per ha.

with a poor copper supply are only found sporadically. Excessive amounts of copper do not promote susceptibility to enzymatical blackening, so that the effect of copper on blackening has more theoretical than practical interest.

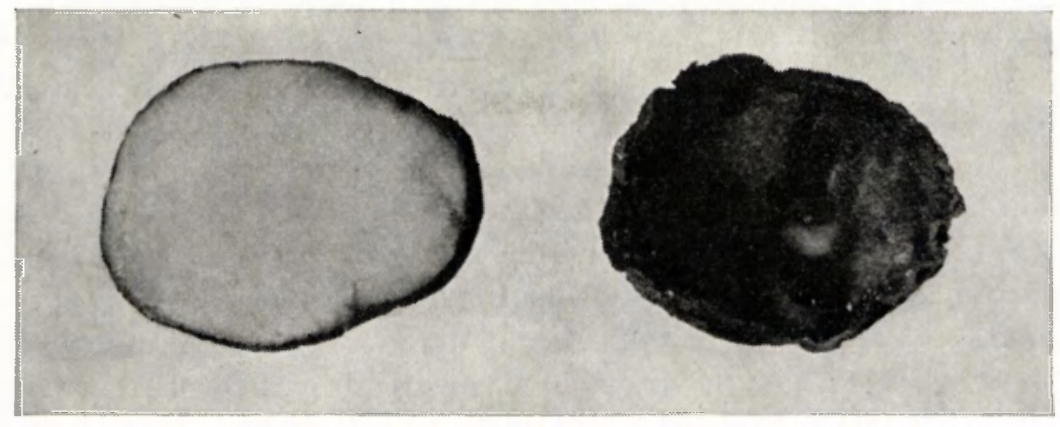

Fig. 3 PotassiUm-deficient potato tUBERS STORED For approximately 9 MONTHS, BRUised, IALVED AND EXPOSED TO THE aIR. Left: tuber from a copper-deficient plant, right: tuber from a plant dressed with copper sulphate.

Cause of the enzymatical blackening

The fact that the blackening of raw potassium-deficient potatoes appears after shaking or cutting the tubers made it seem probable that this phenomenon was caused by an enzymatical reaction. This was borne out by the following experiment. Transverse slices, about $2-3 \mathrm{~mm}$ thick, of potassiumdeficient and normal potatoes, were heated for a few minutes at their centres by a small flame and then exposed to the air. After some hours the state of 
affairs was as follows. In the centre of the slices, where the cells had been killed by the flame and their enzymes inactivated, no discoloration of the tissue was to be seen. In a ring about $5 \mathrm{~mm}$ wide surrounding this white tissue the colour had turned to red and afterwards to black. Apparently the temperature in this ring had been high enough to kill the cells, but the enzymes remained active. In the tissue outside the black ring there was again no discoloration to be seen, owing to the fact that the cells were undamaged.

Although the potassium-deficient tubers in this experiment showed a much more pronounced discoloration than those with a normal K-supply, a distinct ring also developed in the slices of the latter (see Fig. 4). Hence the substances which give rise to the black colour are also present in tubers fully dressed with potassium, though in considerably smaller amounts.

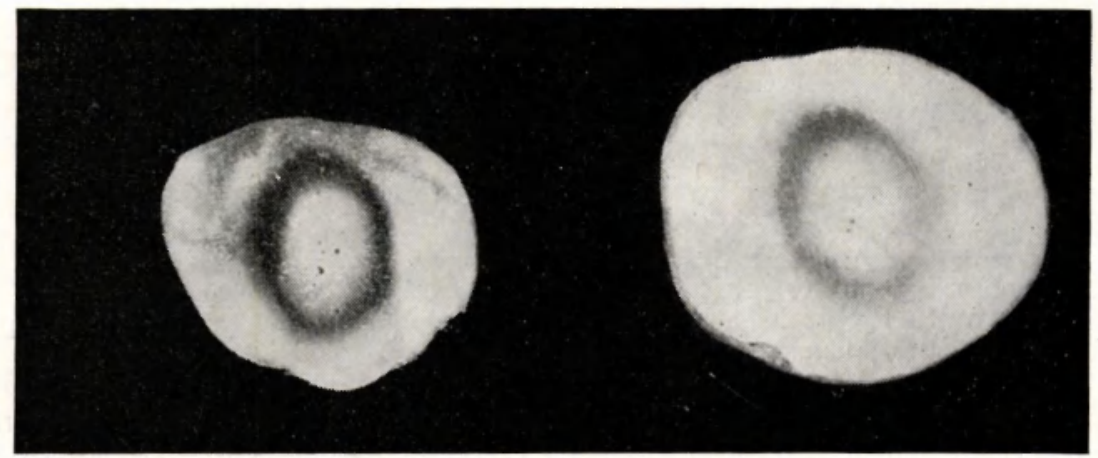

Fig. 4 Discs of K-defichent (LEFT) and Normal (Right) NoORdeling potatoes, heated in THE CENTRE BY A SMall FLAME AND THEN EXPOSED TO THE AIR FOR A FEW HOURS.

In a further experiment potato slices were exposed to toluene vapour. It is a well-known fact that in such an atmosphere the cells are killed but the enzymes remain active. In conformity with this fact first a reddish, and then a bluish-black discoloration of the tissues was produced, as in the case of the bruised tubers. In $\mathrm{K}$-deficient tubers the discoloration following toluene treatment was again much more intense than in normal ones.

The results of these experiments clearly show that the blackening of bruised living potatoes is due to an enzymatic reaction. It is a well-known fact that in both animal and plant tissues black discolorations may be brought about by an enzymatic formation of melanin from tyrosine or other mono- or dihydric phenols. In this reaction tyrosine is oxidized by tyrosinase (monophenol oxidase, polyphenol oxidase) to 3,4-dihydroxyphenylalanine (dopa). The latter compound is then further oxidized to the corresponding quinone, which is converted into a red compound known as hallachrome. Subsequent changes, which include polymerization, lead to the formation of the blue-black pigment melanin from hallachrome.

Since the blackening of bruised potato tissue also proceeds via a red stage, the tyrosinase reaction was held to be responsible for this phenomenon. Evidence for assumption may be derived from the following facts : 
a) Potassium-deficient tubers which are very prone to discolour have a freetyrosine content three or four times as high as that of tubers with a normal potassium supply which do not darken. Their content of $o$-dihydric phenols is also considerably higher (MULDER, 1949).

b) A pulp or an extract of potassium-deficient tubers exposed to the air first turns red and then reddish-brown, black-brown, and finally black. Under the same conditions tubers with a normal potassium supply give only a greyish-brown pulp or extract. Adjustment of the tyrosine and the $o$-diphenol contents of the latter pulp to their respective levels in K-deficient tissue results, however, in a coloration equal to that developing spontaneously in pulped potassium-deficient tubers.

c) Potatoes grown on a soil poor in both copper and potassium are far less prone to blacken than those grown on a similar soil dressed with copper sulphate. This is accounted for by the fact that tyrosinase is a coppercontaining enzyme. As may be seen from Fig. 2, the tyrosinase activity of the copper-deficient tubers is negligible.

d) No discoloration of $\mathrm{K}$-deficient tubers occurs when the $\mathrm{O}_{2}$-absorption is prevented, e.g. by adding a small amount of $\mathrm{Na}_{2} \mathrm{SO}_{3}$ or immersing the the tissues in water. As the tyrosine-tyrosinase reaction is an oxidation, this result is readily understood.

Although the high tyrosine content of potassium-deficient potato tubers is of great importance in the blackening of the tissues, it is not the sole determining factor. This was concluded from the fact that slices from tubers wellsupplied with potassium, which hardly developed any discoloration after rough handling, nevertheless showed a fairly weak, but clearly perceptible coloured ring on being heated in the centre by a low flame. A similar discoloration was observed when slices of normal tubers were exposed to toluene vapour. Although the resulting colour was much weaker than that developed in the potassium-deficient tuber slices, apparently the small amount of tyrosine and $o$-dihydric phenols in the former was nevertheless sufficient to produce this discoloration. Another fact pointing in the same direction is that the stem halves of potassium-deficient tubers which become much more blackened than the top halves after rough treatment, contained only 20-40\% more tyrosine, while the tyrosinase activity in both parts was about equal. Apparently another factor besides the high tyrosine content must be responsible for the extreme liability of K-deficient tubers to discolour. As the tyrosinase reaction can only occur when tyrosine (or $o$-dihydric phenols), tyrosinase and $\mathrm{O}_{2}$ all come together, the obvious assumption is that these conditions are much more easily fulfilled in potassium-deficient than in normal tubers. Tis s u e of the heel halves of the formertubersis much more liable to bruise than that of tubers with an abundant potassium supply. This was demonstrated in the following experiment. Potassiumdeficient and normal tubers were shaken gently in a bottle for some minutes. They were then halved longitudinally. After being washed with tap water the cut surface of one half was inoculated with a culture of the saprophytic Bacterium prodigiosum; the other half remained uninoculated. As Bacterium prodigiosum is unable to develop on living potato tissue its growth indicates that the cells are dead. It was found that there was only an abundant develop- 
ment of the bacterium on those parts of the K-deficient tubers where a black discoloration was to be seen in the corresponding uninoculated halves. On the tubers with a normal K-supply, which after shaking showed no discoloration, there was no growth of Bacterium prodigiosum. When, however, these tubers were boiled for a few minutes before inoculation, there was an abundant growth over the whole of their cut surface.

The fact that the tyrosinase reaction only proceeds when the cells are damaged does not necessarily mean that in the intact cells tyrosine (and $o$-dihvdric phenols) and tyrosinase have different locations, e.g. tyrosine in the vacuole and tyrosinase in the protoplasm. It may be explained equally well by assuming that a powerful reduction system prevents the oxidation of tyrosine in the living cell. Injury to the cells may destroy this reduction system, with the result that the oxydation of tyrosine can proceed. A system of this kind may be easily realized in vitro by adding a few $\mathrm{mg}$ of ascorbic acid to a potato macerate containing 3,4-dihydroxyphenylalanine (dopa) and tyrosinase. As long as ascorbic acid is present no oxidation of dopa takes place, even when air is bubbled through the solution. When the ascorbic acid has been completely oxidized, oxidation of dopa will commence.

\section{Blackening after boiling}

In the literature much more attention has been paid to the blackening of potato tubers after boiling than to the enzymatical blackening (for a survey of this literature see MuLDER 1949).

The opinion voiced by various writers as to the cause and control of "blackening after cooking" are so conflicting that it is highly probable that the phenomena described are due to different causes. No data are available in the literature concerning the relation between the discoloration of living and boiled potatoes, for which reason the present writer made a comparison between the two phenomena. For this investigation use was made of tubers of the Ncordeling variety, grown at different potassium levels of the soil. As described above, these tubers had a different susceptibility to enzymatical blackening. After being peeled the potatoes were placed in enamel pans containing cold tap water and boiled. Then they were exposed to the air for half an hour and compared with similar samples which had been left uncooked, but, after being halved longitudinally, had been exposed to the air overnight. Tubers from plants with heavy symptoms of K-deficiency, which before boiling already showed relatively large areas of blue-black tissue, retained their black colour on boiling. Those from plants with less heavy symptoms of K-deficiency, although practically free from any discoloration before boiling, showed comparatively large areas of pale bluish-green tissue at the stem end when boiled. Tubers from plants with a moderate potassium supply became slightly discoloured after boiling, while those from plants with a heavy K-dressing remained uncoloured.

When the boiled potatoes were compared with the corresponding raw ones which had been exposed to the air overnight, it was found that the discoloration of the former was mainly confined to areas which in the raw potatoes had blackened. In addition to this stem-end discoloration a distinct bluish-green colour had developed in a few cell layers just beneath the peel of the boiler K-deficient potatoes. 
These results demonstrate that discoloration of boiled potatoes may be due to potassium deficiency. Apparently factors which promote blackening in raw potatoes (high tyrosine and $o$-diphenol contents) also promote discoloration after cooking.

To decide whether the grey bluish-green pigment in cooked K-deficient potatoes is melanin or an iron compound, the coloured tissue may be treated with acetic acid. Melanin is unchanged, but if the colour is caused by an iron compound it will disappear.

When the potatoes of the above-mentioned experiment were treated with acetic acid, the bluish-black areas of the K-deficient tubers already present before boiling remained unchanged; on the other hand there was a complete disappearance of the more bluish-green areas at the stem end of these tubers, which were uncoloured before boiling and of the bluish-green surface layer just beneath the peel. This shows that the discoloration which occurs after boiling potato tubers is not caused by melanin formation. As it was found particularly in those tissues relatively rich in o-dihydric phenols, it is assumed that the ferrous compounds of these phenols are formed which become oxidized to the corresponding ferric compound upon exposure to the air. When cocked slices of both potassium-deficient and normal tubers were soaked in a one per cent $\mathrm{FeSO}_{4}$-solution and exposed to the air, a deep bluish-green colour developed, particularly in the tissues outside the vascular ring, and much more clearly at the stem end than at the bud end. This discoloration was much more pronounced in the potassium-deficient tubers than in the normal ones.

Treatment of slices from normal tubers, either before or after boiling, with a solution of an $o$-dihydric phenol caused no discoloration after exposure to the air. Since no difference was found between $\mathrm{K}$-deficient and normal tubers in content of iron soluble in dilute acetic acid, it must be concluded that the $\mathrm{Fe}$-compound of $o$-dihydric phenols is produced more readily in the former than in the latter. This agrees with the observation made by Juuc (1949) who believes that the $\mathrm{pH}$ of the tuber tissue determines the degree of discoloration. In the experiments, made by the present writer, the difference in $\mathrm{pH}$ between normal and K-deficient tubers was so small, however, that it cannot account for the difference in discoloration. Since treatment with citrate considerably lessened the degree of discoloration of boiled K-deficient tubers, it is believed that owing to the low content of citric acid in these tubers the iron reacts more easily than it does in normal tubers which, according to Juol (1949), contain much more citric acid.

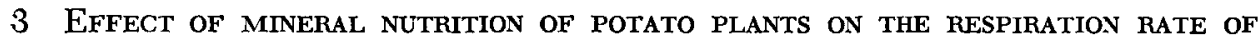
THE TUBERS ${ }^{4}$ )

Potatoes grown on experimental plots under widely differing nutritional conditions were used for the investigations on respiration. In these experiments 1-litre flasks containing about $250 \mathrm{~g}$ tubers were mostly used. Air freed from $\mathrm{CO}_{2}$ was passed through these flasks at the rate of approximately 20 litres per hour. The $\mathrm{CO}_{2}$ produced was absorbed in baryta. Temperature $25^{\circ} \mathrm{C}$. In a number of experiments, particularly in those in which different gas mixtures

4) For a more detailed account of these investigations, see Mulder (1955). 
were employed, $\mathrm{O}_{2}$-absorption was measured manometrically by the Warburg method. For this purpose large $150-\mathrm{ml}$ vessels were used in which the potato tubers were placed on a small net over $\mathrm{KOH}$.

Many experiments were carried out with $1-\mathrm{mm}$ thick tissue discs. These discs were cut by a microtome from cylinders obtained by means of a cork borer. Before use the dises were washed approximately 25 times in tap water or distilled water. In contrast to the orthodox methods the tissue discs were not suspended in buffer solution but respired in damp air. The advantage of this procedure is that no difficulties are caused by inadequate diffusion of oxygen into the buffer solutions. The same is true of bacterial infections which hardly occur, or if so can be readily recognized. The vessels were usually kept in a water bath at $25^{\circ} \mathrm{C}$ in which diffuse light could penetrate. In control experiments no effect of this weak light on respiration could be detected. Only in cases where a light effect was to be expected (experiments with $\mathrm{CO}$-treated discs) was the light completely excluded.

Fig. 5 gives the respiration rates, calculated as $\mathrm{mg} \mathrm{CO}_{2}$ per hour per $100 \mathrm{~g}$ of fresh tissue, of potato tubers deficient in nitrogen, phosphorus, potassium, magnesium and copper, respectively, as compared with tubers grown on the
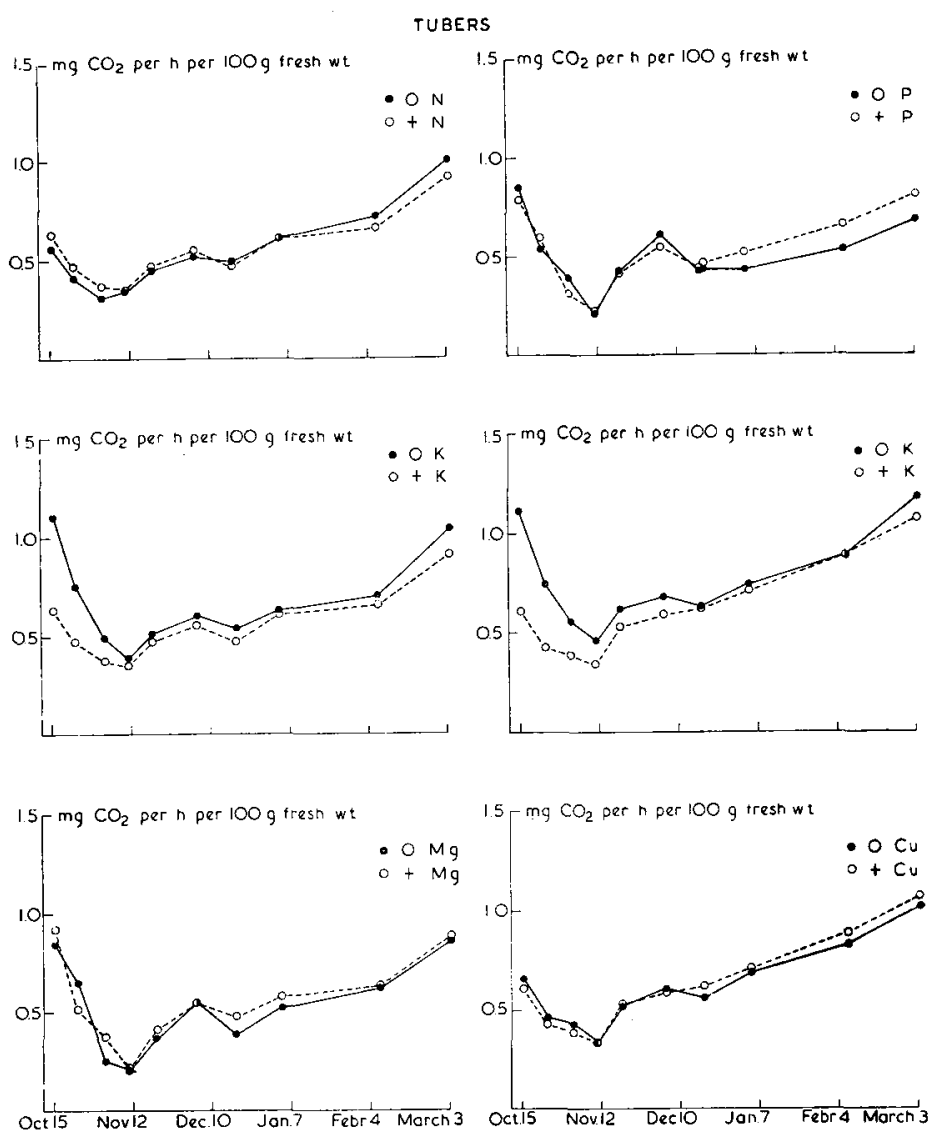

Fig. 5 Effect of the mineral nutrition of potato plants on the $\mathrm{CO}_{2}$-evolution of THE TUBERS. 
same experimental fields in the presence of adequate amounts of these nutrient elements. The experiment was started soon after harvesting the potatoes at the beginning of October 1951 and was continued until March 1952. During this period the tubers were left untouched in the vessels.

Nitrogen, phosphorus, magnesium, copper

Although the potatoes used in this experiment came from plants which had shown severe deficiency symptoms (see the yield data in Table 8), no differences in respiration rate were observed in the case of nitrogen, magnesium and copper.

Table 8 Yield data of potatoes used in the respiration experiments (cf Fig. 5).

\begin{tabular}{|c|c|c|}
\hline Experimental field, variety & $\begin{array}{l}\text { Manurial treatment } \\
\left(\mathrm{kg} \text { per ha) }{ }^{1}\right)\end{array}$ & $\begin{array}{l}\text { Yield, q per ha } \\
(1 \mathrm{q}=100 \mathrm{~kg})\end{array}$ \\
\hline $\begin{array}{l}1011 \text {, Noordeling } \ldots \ldots \ldots \ldots \\
1181 \text {, Noordeling } \ldots \ldots \ldots \ldots \\
1113 \text {, Vora.1 } \ldots \ldots \ldots \ldots \ldots \\
1220 \text {, Voran } \ldots \ldots \ldots \ldots \ldots\end{array}$ & $\begin{array}{l}\text { no potassium, } 50 \mathrm{CuSO}_{4} \\
300 \mathrm{~K}_{2} \mathrm{O}, 50 \mathrm{CuSO} \\
300 \mathrm{~K}_{2} \mathrm{O}, 0 \mathrm{Cu} \\
40 \mathrm{~N}, 300 \mathrm{~K}_{2} \mathrm{O} \\
160 \mathrm{~N}, 300 \mathrm{~K}_{2} \mathrm{O} \\
160 \mathrm{~N}, 25 \mathrm{~K}_{2} \mathrm{O} \\
\text { no phosphorus } \\
140 \mathrm{P}_{2} \mathrm{O}_{5} \\
5 \mathrm{MgO} \\
160 \mathrm{MgO}\end{array}$ & $\begin{array}{r}69 \\
179 \\
170 \\
216 \\
294 \\
163 \\
53 \\
294 \\
161 \\
383\end{array}$ \\
\hline
\end{tabular}

1) Basal dressing was applied in optimum amounts.

In the case of phosphorus, a small difference in respiration rate was found between deficient and normal tubers in the second part of the experiment.

\section{Potassium}

Marked differences were obtained between potatoes with a different potassium supply. K-deficient tubers respired more intensively than tubers with an adequate $\mathrm{K}$-supply. This was particularly clear in the beginning of the experimental period. In the course of this period the differences became smaller. Towards the spring they tended to increase.

Since it is a well-known fact that potatoes with a different manurial treatment may have a different dry-matter content and a different protein content, the respiration rates of this experiment were also calculated on a protein basis. In this case the nitrogen-deficient tubers gave higher values than those supplied liberally with nitrogen. Apparently the protein formed in excess of the protein of $\mathrm{N}$-deficient tubers did not take part in metabolic processes. In the case of phosphorus the differences between deficient and normal tubers became more pronounced if calculated on protein, whereas in the case of potassium the differences were reduced. This was due to the fact that the protein content of $\mathrm{P}$-deficient and $\mathrm{K}$-deficient tubers was higher than that of normal tubers.

The important effect of K-supply on respiration rate of potato tubers was also shown in a number of subsequent experiments (cf. Table 9). The tubers from $\mathrm{K}$-deficient plants always produced considerably more $\mathrm{CO}_{2}$ than those from plants dressed normally with potassium. 
Table 9 Effect of potassium nutrition of Noordeling potato plants on the respiration rate of the tubers.

\begin{tabular}{|c|c|c|c|c|c|}
\hline \multirow[t]{2}{*}{ Experiment and date } & \multirow[t]{2}{*}{ Time } & \multicolumn{2}{|c|}{$\begin{array}{l}\text { Yield, } \\
\text { q per ha }\end{array}$} & \multicolumn{2}{|c|}{$\begin{array}{l}\text { mg } \mathrm{CO}_{2} \text { per hour per } \\
\mathrm{l} 60 \mathrm{~g} \text { fresh weight }\end{array}$} \\
\hline & & $0 \mathrm{~K}$ & $+\mathrm{K}$ & $\mathrm{OK}$ & $+\mathrm{k}$ \\
\hline 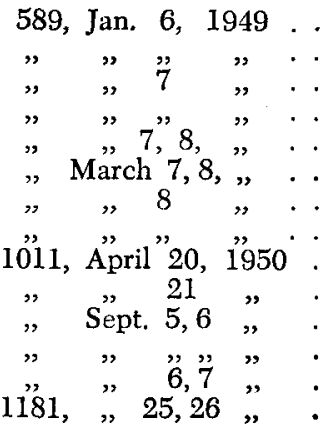 & $\begin{array}{c}12-17 \\
17-24 \\
24-10 \\
10-16 \\
17-9 \\
23.30-9.30 \\
9.30-16 \\
18-9.30 \\
17-19 \\
10-14 \\
18-9 \\
11-16 \\
17-9 \\
17-9\end{array}$ & $\begin{array}{r}136 \\
74\end{array}$ & $\begin{array}{l}250 \\
193\end{array}$ & $\begin{array}{l}1.07 \\
2.00 \\
2.16 \\
2.20 \\
2.24 \\
1.74 \\
1.89 \\
1.98 \\
3.22 \\
3.60 \\
3.27 \\
3.09 \\
2.82 \\
3.14\end{array}$ & $\begin{array}{l}0.69 \\
1.34 \\
1.34 \\
1.32 \\
1.17 \\
1.18 \\
1.51 \\
1.76 \\
1.82 \\
1.74 \\
2.38 \\
1.86 \\
1.77 \\
1.63\end{array}$ \\
\hline
\end{tabular}

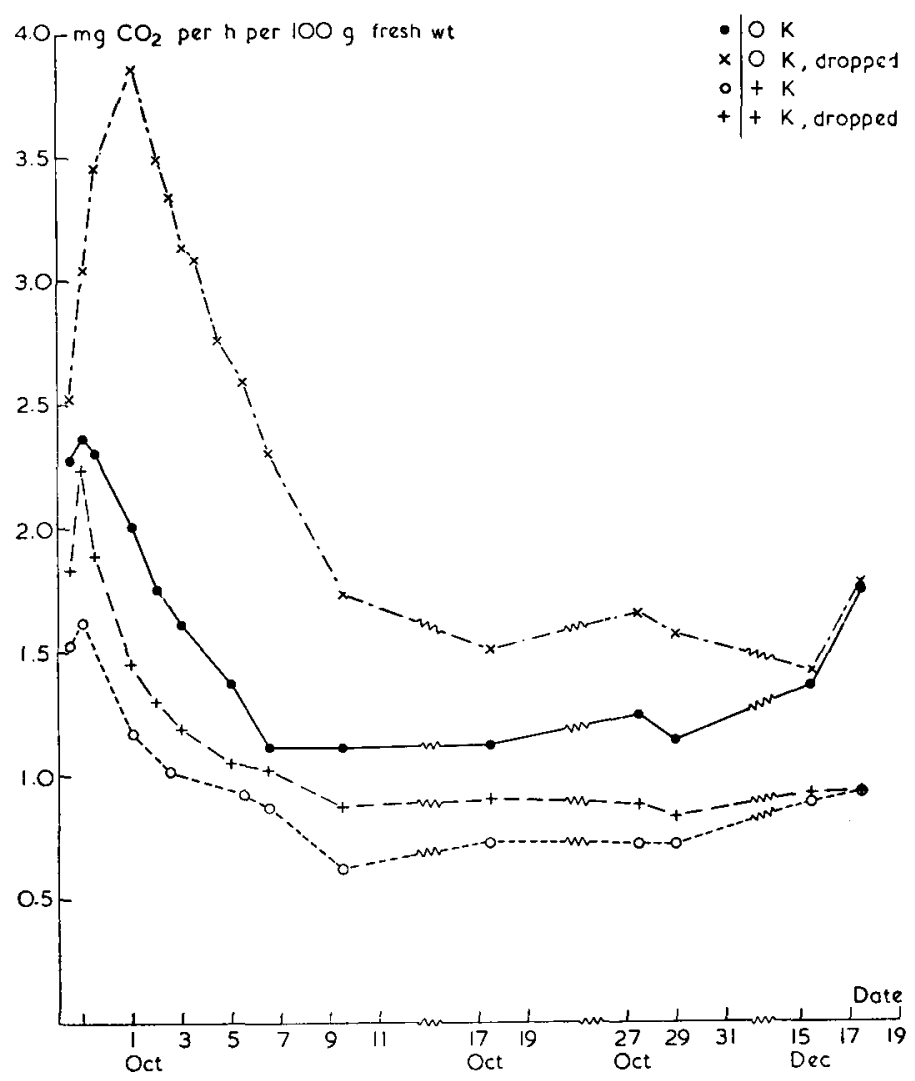

Fig. 6 EFFECT ON $\mathrm{CO}_{2}$-EVOLUtion OF THE BRUISING OF POTASSIUM-DEFICIENT AND NORMAL POTATO TUBERS (NOORDELING VAR.). The tubers were dropped once from a height of $1 \mathrm{~m}$ on to a wooden floor on Sept. 28, 1950.

The differences in $\mathrm{CO}_{2}$-production between $\mathrm{K}$-deficient and normal potatoes were found to be most pronounced at the beginning of the experiment; they 
decreased when the tubers remained in the respiration vessels for a prolonged period. This suggested that they depend on variations in sensitivity to handling of these tubers. To verify this hypothesis the following experiment was carried out. Tubers from potassium-deficient and normal plants were dropped once from a height of one metre on to a wooden floor before being transferred to the respiration vessels. Fig. 6 shows the results of this experiment. It will be seen that in the case of potassium-deficient tubers, carbon dioxide production rose enormously upon dropping. The increased respiration rate was maintained for a considerable length of time. Tubers from normal plants also had increased respiration rates upon dropping, but the rise in $\mathrm{CO}_{2}$-production was much less pronounced than in the case of potassium-deficient ones.

The results of these experiments agree with those of the above-mentioned investigations into enzymatical blackening. In these investigations it was found that K-deficient tubers are much more liable to blackening than tubers
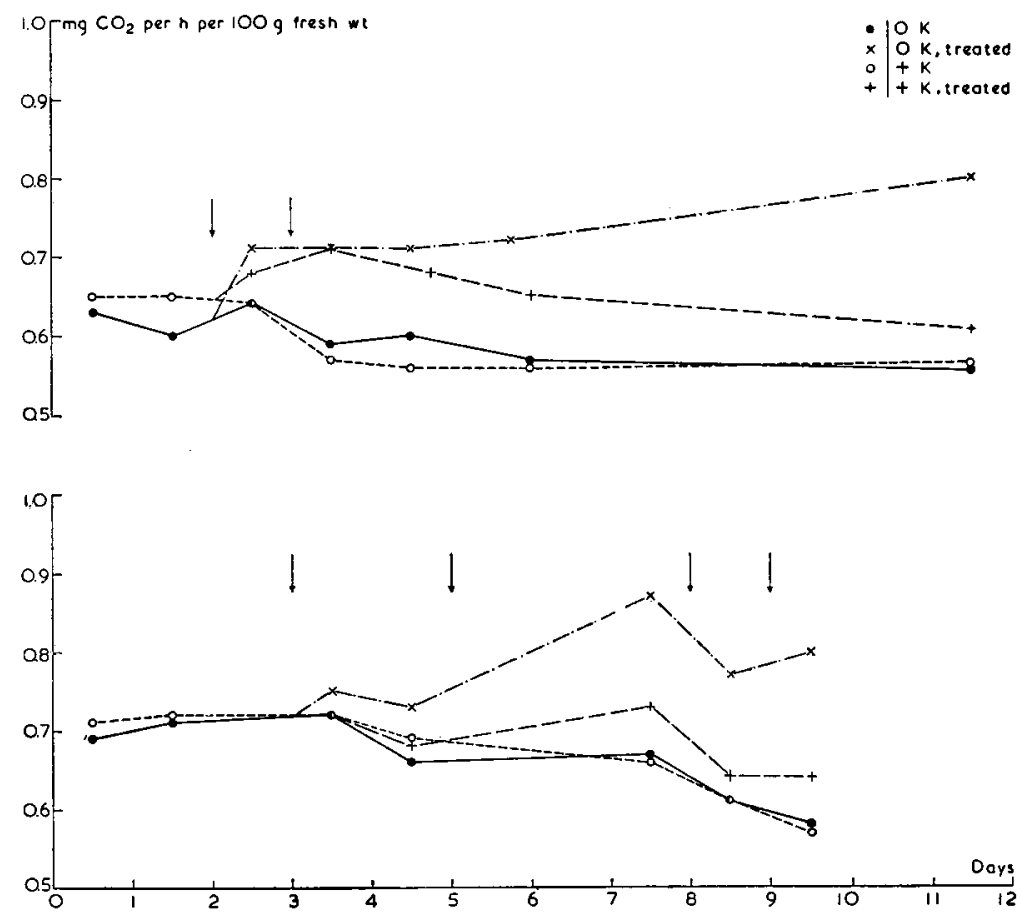

Fig. $7 \mathrm{CO}_{2}$-EVolUtion of POTASSIUM-DEFICIENT AND NORMAL POTATO TUBERS (NOORDEt.ING VAR.) haRVESTED AND TRANSFERRED VERY CAREFULLY. Arrow: a number of tubers were dropped in a box covered with cotton-wool. Tubers transferred to respiration bottles on December 8, 1954 (lower graphs) and on January 5, 1955 (upper graphs). Measurements of respiration rate were begun 5 days later.

with an adequate $\mathrm{K}$-supply, owing to the fact that they are much more liable to bruising; in addition, their content of tyrosine and $o$-dihydric phenols is much higher. The bruising of large parts of tuber tissue is apparently the cause of the increased respiration rate of K-deficient potatoes. This may be concluded from the following results :

a) Stem halves of K-deficient potatoes which are much more sensitive to bruising than top halves respire more intensively than the latter. 
b) Potassium-deficient potatoes harvested and transported to the laboratory in such a way as to prevent any rough handling, respired at a rate similar to that of normal tubers. A slight movement of these tubers (removal of shoots, dropping in a box covered with cotton-wool) caused differences in respiration rate (see arrows in Fig. 7). In this case no black discolorations could be detected in the potassium-deficient tubers, unlike the experiments in which large differences in $\mathrm{CO}_{2}$-production were observed between tubers with a different potassium supply.

\section{Cause of the increased respiration rate of K-deficient potatoes}

From the results of the above-mentioned experiments it may be concluded that the enhanced liability to bruising of the tubers is the main cause of the increased respiration rate where there is potassium deficiency. Cell respiration of K-deficient tubers was found to be similar to that of normal tubers. This may be concluded from the results of experiments with tissue discs (see Fig. 8).

When tissue discs were damaged, respiration rate was not increased, but was lower than that of undamaged discs. Similarly discs cut from bruised tubers gave lower respiration rates than those from undamaged tubers. Apparently cutting has the same effect on respiration rate as bruising, so that bruising of freshly cut discs does not promote further respiration. These results also show that it is not the wounded cells which give rise to the increased respiration rate, but the living cells, activated in some unknown way by the wounded cells.

The following experiments showed that wounding as such, and not improved oxygen supply, is responsible for the large increase in respiration rate of tissue discs and wounded K-deficient potatoes. Potassium-deficient

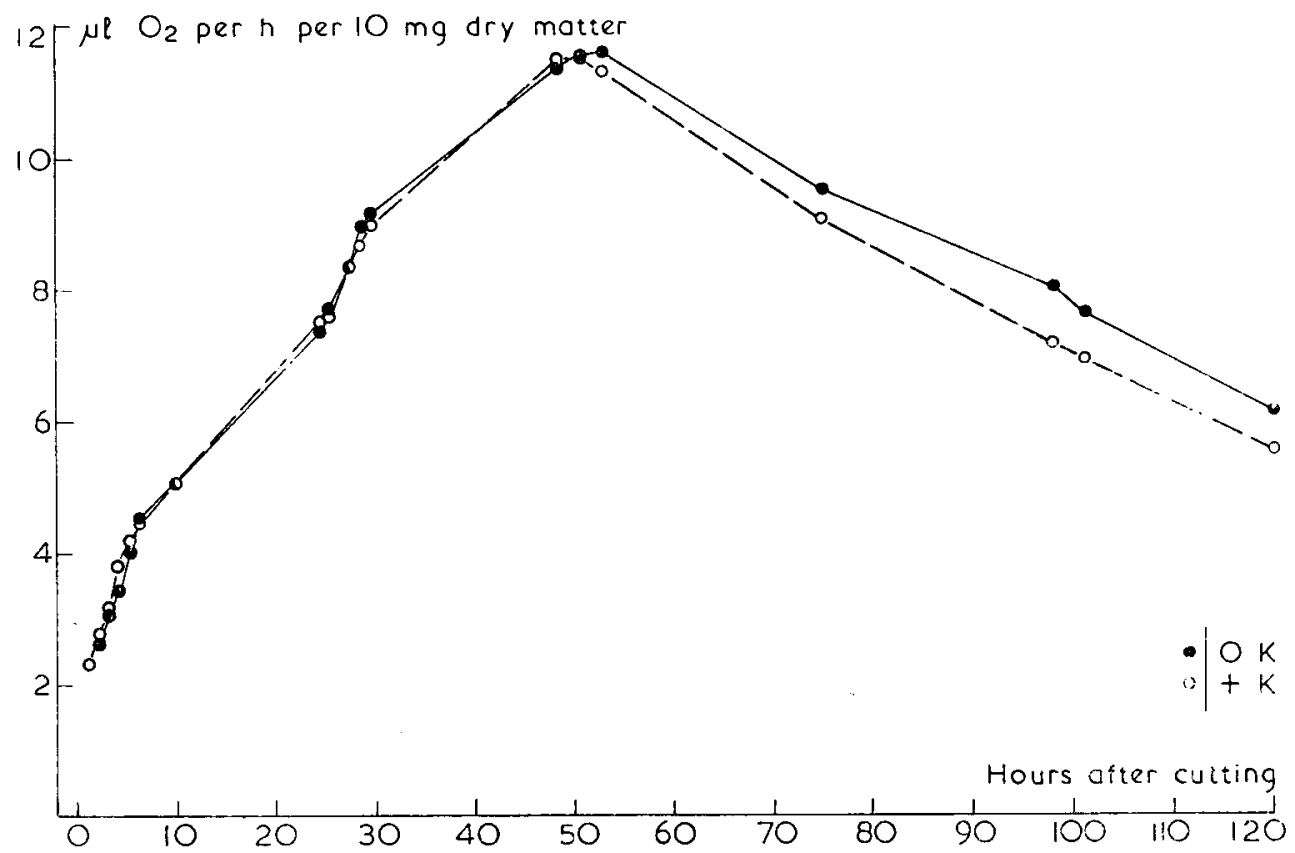

Fig. 8 EfFect of potassium nutrition of potato plants (NOORDEling) ON OXYgen absorptION OF $1 \mathrm{MM}$ THICK TUBER DISCS RESPIRING IN MOIST AIR. The drop in respiration rate on the third day was partly due to loss of water. Discs cut on January 24, 1955. 
and normal tubers were cut longitudinally and rinsed quickly with distilled water. The cut surface was then covered with paraffin wax to prevent penetration of $\mathrm{O}_{2}$ through this surface. As will be seen from the data of Table 10, increase of $\mathrm{CO}_{2}$-production of such tubers was nearly as high a that of uncovered halved tubers.

Table 10 Effect of halving on $\mathrm{CO}_{2}$-production of potato tubers.

\begin{tabular}{|c|c|c|}
\hline \multirow[t]{2}{*}{ Treatment } & \multicolumn{2}{|c|}{$\begin{array}{c}\mathrm{mg} \mathrm{CO}_{2} \text { produced per } \mathrm{h} \text { per } 100 \mathrm{~g} \\
\text { of fresh tissue }\end{array}$} \\
\hline & $0 \mathrm{~K}$ & $+\mathrm{K}$ \\
\hline Control (untreated) & 3.14 & 1.63 \\
\hline Halved $\ldots \ldots \ldots \ldots \ldots \ldots \ldots \ldots \ldots$ & $5.80(2.66) 1)$ & $4.70 \quad(3.07)$ \\
\hline Halved + paraffin wax $\ldots \ldots \ldots \ldots$ & $5.06(1.92)$ & $4.14 \quad(2.51)$ \\
\hline
\end{tabular}

1) In parentheses : increase in respiration.

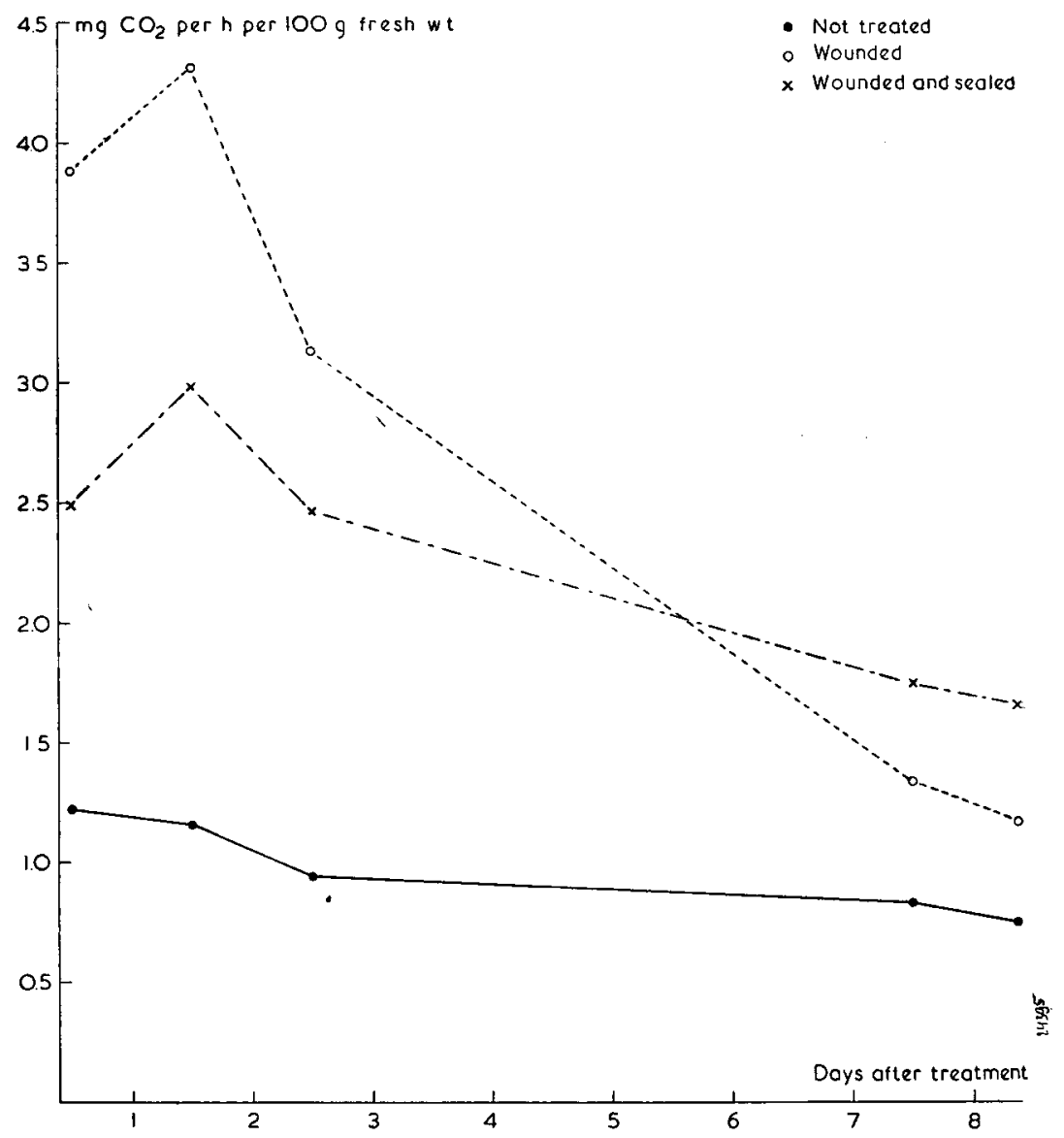

Fig. 9 EFFEct of WOUnding on $\mathrm{CO}_{2}$-Evolution of potato tubers (Noordeling) From NORMAL PLANTS. Wounding was brought about by pushing a cork borer into thestem and bud ends of the tubers (October 10, 1952). In one series the wounds were immediately sealed with paraffin wax to prevent gas exchange through the. wounded surface. 
Similar results were obtained in an experiment in which a sterilized cork borer was pushed into the stem and bud ends of the tubers for $2 \mathrm{~cm}$. Immediately after it had been drawn out again the wound was covered with paraffin wax. The results of this experiment are plotted in Fig. 9. It will be seen that a marked response to wounding was obtained with both covered and uncovered wounds. In the former case respiration rate rose less sharply and continued for a longer period than in the latter case. Apparently oxygen supply through the existing gas spaces was insufficient to allow wound reactions to proceed at optimum speed. This was also shown in an experiment in large Warburg vessels in which damaged and peeled $\mathrm{K}$-deficient potatoes were kept at two different $\mathrm{O}_{2}$-concentrations viz. 20 and $60 \%$. Although in the case of undamaged tubers both $\mathrm{O}_{2}$-concentrations in the gas space gave equal results, $60 \% \mathrm{O}_{2}$ gave considerably higher values than $20 \%$ when the tubers

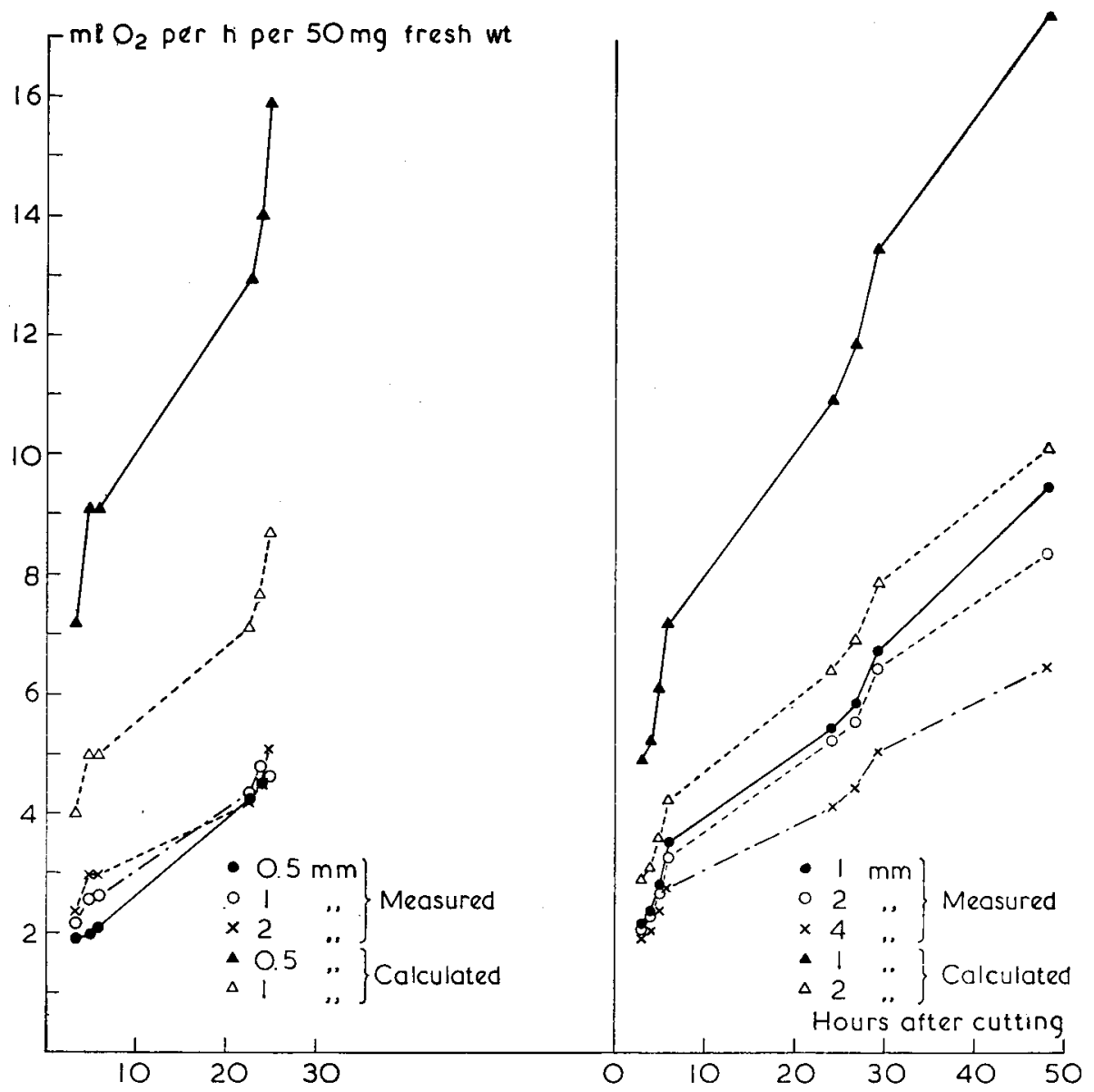

Fig. 10 Oxygen absorption by potato discs of varying thickness. Calculated values WERE DERIVED FROM THE MEASURED VALUES OF $2 \mathrm{~mm}$ (left-hand graph) and $4 \mathrm{~mm}$ (right-hand graph) discs. The calculated values represent oxygen-absorption rates which would have been obtained for 0.5 and $1 \mathrm{~mm}$ discs (left-hand curves) and 1 and $2 \mathrm{~mm}$ discs (right-hand curves) if respiration rates had been proportional to the area of wounded surface. Tubers from plants with optimum manurial treatment (Noordeling var.). Discs cut June 6, 1952 (at left) and December I6, 1954 (on right). 
were wounded. When the potatoes used in this experiment were halved after being kept for 5 days at the respective $\mathrm{O}_{2}$-concentrations, those kept at $20 \%$ $\mathrm{O}_{2}$ were found to have blackened to a considerably greater extent than those kept at $60 \%$. Apparently $20 \% \mathrm{O}_{2}$ was too low to supply the wounded tissue with an adequate amount of $\mathrm{O}_{2}$, as a result of which more cells died and gave rise to blackening.

That the effect of wounding on respiration rate is not confined to the cells adjacent to the cut surface can be concluded from the following experiments. Oxygen absorption was measured in discs of $0.5,1$ and $2 \mathrm{~mm}$, and 1,2 and $4 \mathrm{~mm}$ thickness respectively. With equal weights of these discs, the wounded area decreased with increasing thickness at a ratio of $3,2: 1,7: 1$ and $2,7: 1,6: 1$. As will be seen from the data in Fig. 10, respiration rate was proportional to the weight of the discs and not to the area of wounded surface. This means that the stimulus given to the respiration rate by wounding extended throughout the discs. As the slices aged, a surface effect was noticed, presumably caused by the fact that the wounds became sealed, thus preventing oxygen from entering freely.

Comparison of the respiration mechanism of wounded and intact potato tissue

As may be seen from Figures 8 and 9, wounding of potato tubers causes a considerable rise in their respiration rate. In the case of tissue discs a five- to six-fold rise may often be found within 2 days from cutting. Compared with

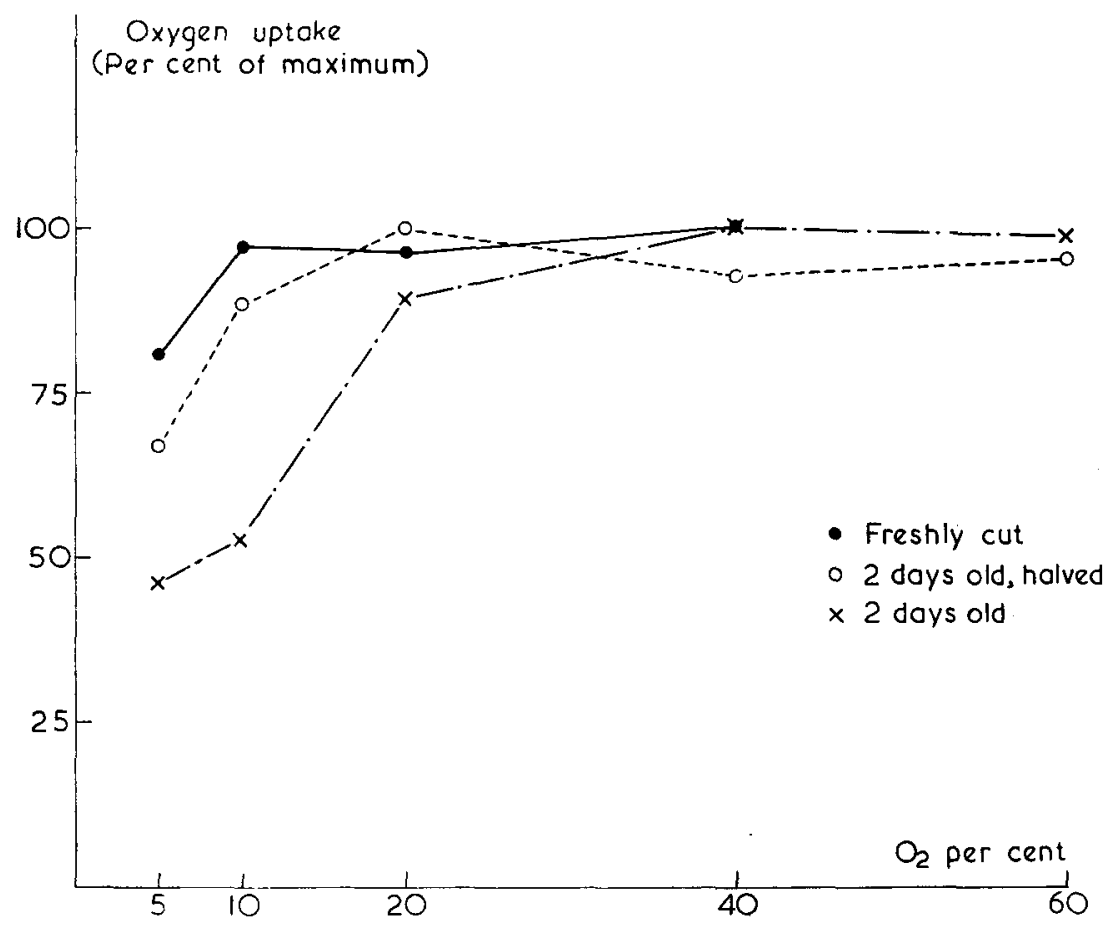

Fig. 11 OXYGEN ABSORPTION BY FRESHLY CUT, 2-DAY OLD AND HALVED 2-DAY OLD POTATO DISCS FROM NORMAL TUBERS (NOORDELING VAR.) AT DIFFERENT $\mathrm{O}_{2}$-TENSIONS OF THE ATMOSPHERE. Values given as percentages of maximum respiration rate. Discs cut December. 2, 1954. 
the resting potato the differences are even considerably larger. In order to study the respiration of intact and wounded potato tissues, a comparison was made between freshly-cut and 2-day old tissue discs. The latter were stored in a damp atmosphere at $20^{\circ} \mathrm{C}$ for 2 days after cutting, before being transferred to the Warburg vessels. It was assumed that respiration of freshly cut tissue is equal to that of intact tissue.

Pronounced differences in the metabolic behaviour were observed between both types of tissue discs. Freshly-cut dises have a considerably lower optimum $\mathrm{O}_{2}$-concentration than 2-day old discs (Fig. 11). They have a much lower tendency to produce carbon dioxide under anaerobic conditions (Fig. 12), and their respiration is more sensitive to inhibiting substances such as cyanide, carbon monoxide and sodium fluoride. Furthermore their catalase and peroxidase contents are much lower than those of 2-day old discs. Their content of diphosphopyridine nucleotide (DPN) is also much lower.

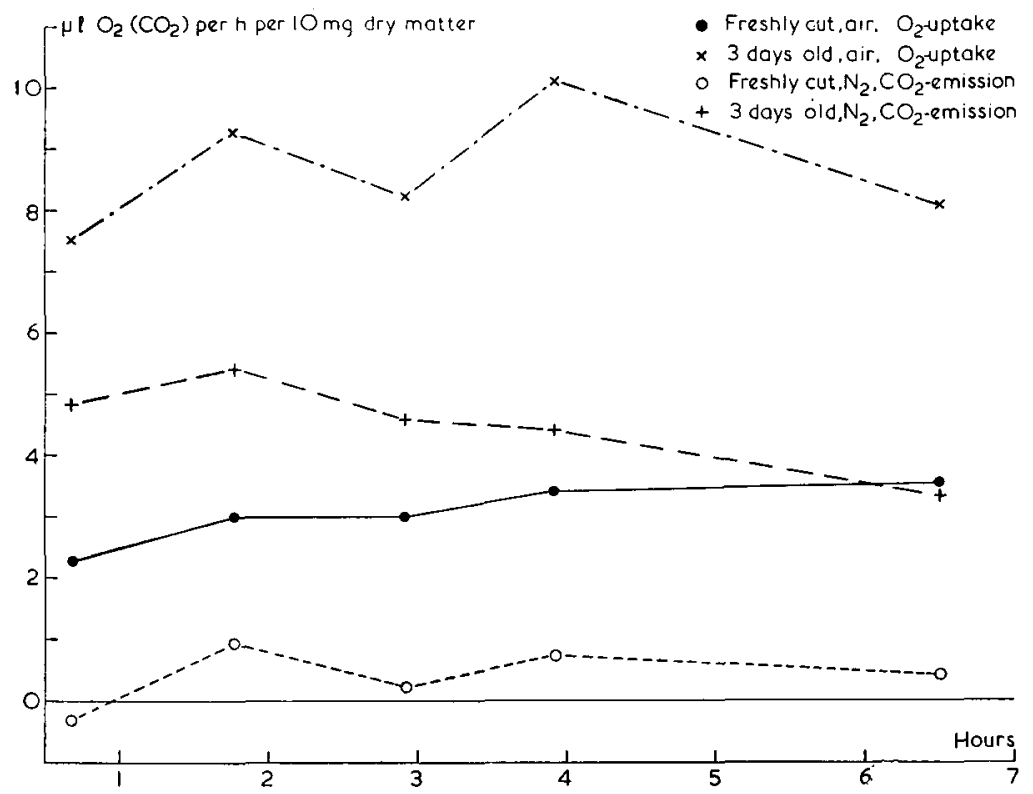

Fig. 12 Oxygen absorption (In aIR) and $\mathrm{CO}_{2}$-Emission (IN $\mathrm{N}_{2}$ ) of Freshly CUT and 3-Day OLd POTATO DISCS OBTAINED FROM NORMAL TUBERS (NOORDEling Var.). Discs cut April 9, 1952.

The difference in behaviour between young and old discs may be partly ascribed to a hampered entry of oxygen and of the inhibiting substances into the 2-day old discs, as compared with the entry of these gases in freshly cut discs. This is concluded from the fact that 2-day old discs of $2 \mathrm{~mm}$ thickness divided into two discs of $1 \mathrm{~mm}$ each behave more or less like freshly cut discs as to optimum rate of oxygen (Fig. 11) and sensitiveness with respect to cyanide and carbon monoxide. Sensitiveness to $\mathrm{NaF}$, which in young discs is very high, was only partly restored by halving 2-day old discs.

\section{Copper}

The copper-containing enzyme tyrosinase is considered by some authors (Boswell and Whiting 1938) to act as a terminal oxidase in potato tubers. This 
assumption has been denied by Levy and Schade (1948), Schade et al. (1948), Schade and Levy (1949) and by Thimann et al. (1954), who have provided evidence that cytochrome oxidase acts as the main terminal oxidase in potato tubers. On p. 340 mention was made of the poor tyrosinase activity of potato tubers grown on soils very poor in available copper. If tyrosinase had the function of a terminal oxidase in potato tubers it might be assumed that differences would exist between the respiration rates of copper-deficient and normal potato tissues. The respiration rates of copper-deficient and normal tubers where therefore compared. The results of such an experiment are plotted in Fig. 5. No difference in $\mathrm{CO}_{2}$-production was found between copperdeficient and normal tubers. In subsequent experiments it was found that different tubers grown on the same copper-deficient plots differed considerably in tyrosinase activity. For this reason only those tubers were used in the
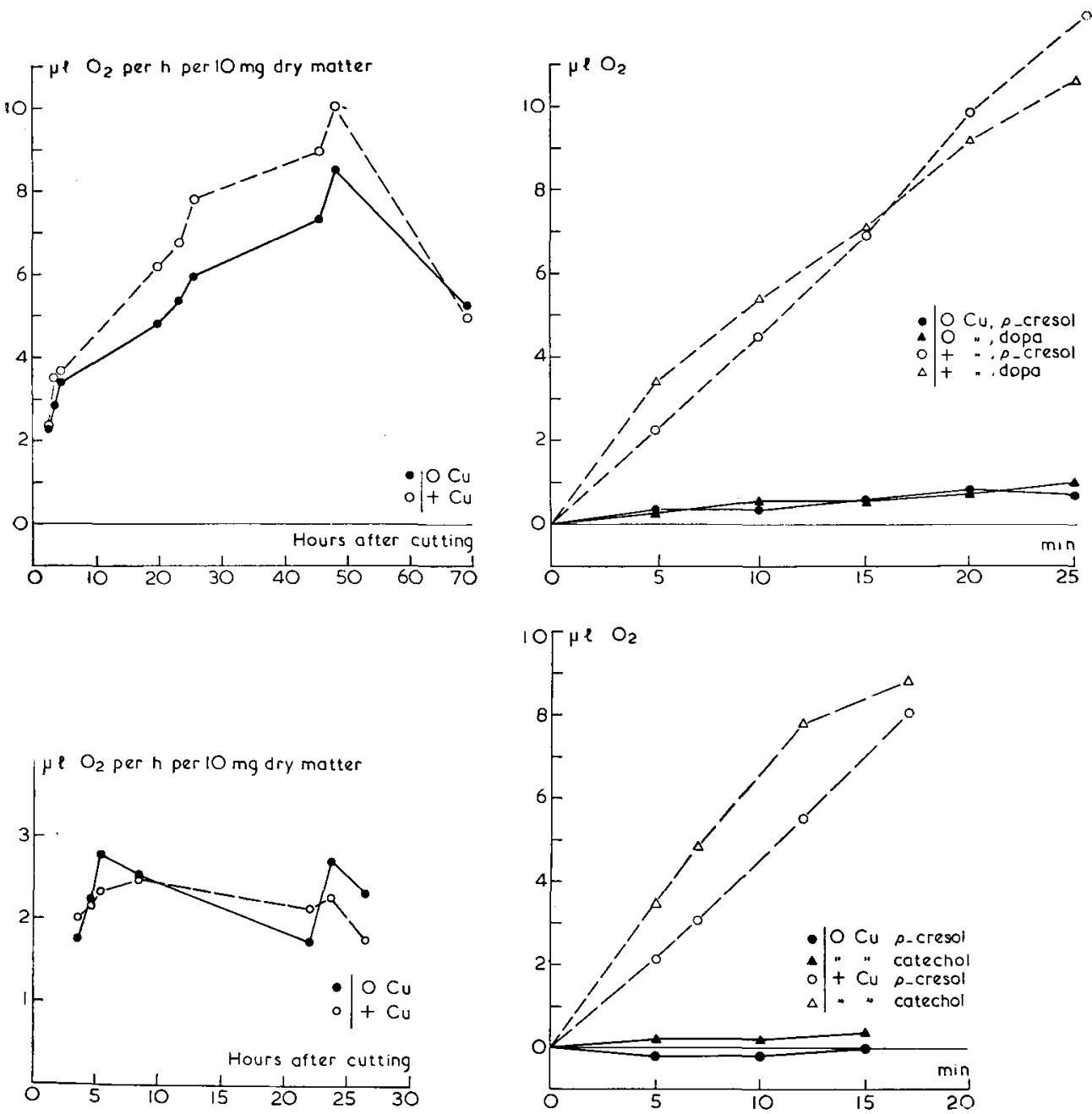

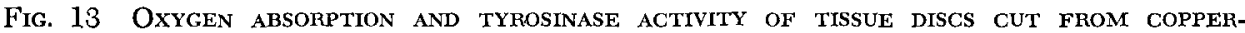
DEFICIENT AND NORMal POTATO TUBERS RESPECTIVElX (NOORDELING Var.). Upper two graphs : discs from relatively young tubers (stored from October-February), lower two : discs from old tubers (stored from October-June). 
respiration experiments which were found to be practically free from tyrosinase. This was tested by cutting a small piece of tissue from the tubers and reacting with a solution of dopa. Since the tyrosinase content of potatoes was found to decrease as the tubers aged, most respiration experiments were carried out with relatively old tubers.

Although many experiments were made with potatoes practically free from tyrosinase, no differences were found between the $\mathrm{CO}_{2}$-production of these tubers and tubers with a normal supply of copper. Pealing of such tubers, although it considerably increased the respiration rate, did not bring about a difference between the two types of tubers.

In experiments with discs cut from copper-deficient and normal potatoes, in a number of cases equal respiration rates were found for both types of tissue, although tyrosinase was completely absent in the copper-deficient tissue. Since complete absence of tyrosinase was only found in old potato tubers, these conclusions apply to these tubers only (see Fig. 13). It will be seen that the rise in respiration rate after cutting which is found in young tubers, did not occur in the discs cut from these old tubers.

In some cases, however, it was found that the copper-deficient discs had lower respiration rates than discs cut from normal tubers. Since old copperdeficient potatoes were often found to have a very poor turgidity, it was assumed that in this case the observed effect of copper on respiration rate was due to some secondary effect of this element.

In a number of experiments with relatively young potatoes in which respiration rate rose normally after cutting, it was found that the rise in respiration of normal discs was more pronounced than in copper-deficient discs (see Fig. 13). This may be an indication that copper is in some way connected with the stimulation of respiration after wounding.

\section{REFERENCES}

Boswell, J. G. and G. C. Whiting: A study of the polyphenol oxidase system in potato tubers. Ann. Botany N.S. 2 (1938) 817-863.

Levy, H. and A. L. Schade: Studies in the respiration of the white potato. II. Termmal oxidase system of potato tuber respiration. Arch. Biochem. 19 (1948) 273-286.

Juul, F. : Studier over kartoflens mørkfarvning efter kogning. Thesis, København (1949).

Mulder, E. G. : Mineral nutrition in relation to the biochemistry and physiology of potatoes. 1. Effect of nitrogen, phosphate, potassium, magnesium and copper nutrition on the tyrosine content and tyrosinase activity with particular reference to blackening of the tubərs. Plant and Soil 2 (1949) 59-121.

- - : Effect of mineral nutrition of potato plants on respiration of the tubers. Acta Botanica Neerlandica 4 (1955) 429-451.

- - and K. BakEMA : Effect of the nitrogen, phosphorus, potassium and magnesium nutrition of potato plants on the confent of free amino-acids and on the amino-acid composition of the protein of the tubers. Plant and Soil 7 (1956) 135-166.

Schade, A. L., L. Bergmann and L. Beyer: Studies on the respiration of the white potato. I. Preliminary investigation of the endogenous respiration of potato slices and catechol oxidase activity. Arch. Biochem. 18 (1948) 85-96.

- - and H. Levy : Studies on the respiration of white potatoes. III. Changes in the terminal oxidase pattern of potato tissue associated with time of suspension in water. Arch. Biochem. 20 (1949) 211-229.

Thrmany, K. V., C. S. Yocum and D. P. Hackett : Terminal oxidase and growth in plant tissues. III. Terminal oxidation in potato tuber tissue. Arch. Biochem. 53 (1954) 239-257.

Thompson, J. F. and F. C. STEward: The analysis of the alcohol-insoluble nitrogen of plants by quantitative procedures based on paper chromatography. J. Exp. Botany 3 (1952) $170-187$. 